\title{
Non-Keynesian Effects of Fiscal Policy in the EU-15 ${ }^{(*)}$
}

\author{
António Afonso ${ }^{(* *)}$ \\ Department of Economics, Instituto Superior de Economia e Gestão, \\ Universidade Técnica de Lisboa, \\ R. Miguel Lúpi, 20, \\ 1249-078 Lisbon, Portugal
}

This version: May 2001

\begin{abstract}
The possibility of the so called "non-Keynesian" was illustrated by several fiscal episodes in Europe during the last two decades, giving rise to a growing body of both theoretical and empirical literature. The purpose of this paper is twofold. First, a simple two period model for private consumption is presented in order to explain the possibility of both Keynesian and non-Keynesian effects of fiscal policy, the main feature being the relation between interest rate and taxes and the existence of rationed consumers. Second, and in order to evaluate the empirical evidence for Europe, panel data models for private consumption are estimated for the EU-15 countries, using annual data over the period 1970 to 1999. The estimation results for the 15 EU countries show some evidence that fiscal policy has the standard Keynesian effects when there are no fiscal adjustments. However, in the presence of fiscal adjustments the traditional Keynesian effects may become non-Keynesian. This reversion occurs basically when the fiscal adjustment is a contractionary one, and is virtually unimportant when the adjustment is a fiscal expansion, revealing therefore some asymmetric consequences of fiscal policy.
\end{abstract}

Keywords: fiscal policy; expansionary fiscal contractions; non-Keynesian effects

JEL classification: E21; E62

\footnotetext{
(*) This paper is part of the research project for the author's Ph.D. thesis. The author acknowledges comments from Jorge Santos, João Santos Silva, Stephen Miller and from participants at the following conferences: Eastern Economic Association Annual Conference 2001, February, New York; 6th Spring Meeting of Young Economists, March/April 2001, Copenhagen; 2001 Meeting of the European Public Choice Society, April, Paris. The usual disclaimer applies.

${ }^{(* *)}$ Tel.: +351 21392 2807; Fax: +351 21396 6407; e-mail: aafonso@iseg.utl.pt
} 


\section{Contents}

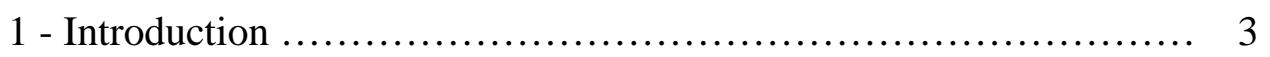

2 - Fiscal policy effects: theoretical issues ........................ 5

3 - A theoretical model for fiscal policy non-Keynesian effects ........ 10

4 - A brief review of the empirical literature ........................ 16

4.1 - How to define "fiscal expansion/contraction"? .................. 16

4.2 - Empirical tests ......................................... 19

5 - Non-Keynesian effects in the EU-15 ........................ 21

5.1 - Fiscal episodes in the EU-15 ........................... 21

5.2 - Estimation of non-Keynesian fiscal effects in the EU-15 ......... 26

5.3 - The success of fiscal consolidations .......................... 34

6 - Conclusion ................................................... 39

Appendix A - Derivation of non-Keynesian effects of fiscal policy on private consumption ................................................. 41

Appendix B - Statistical sources ............................. 42

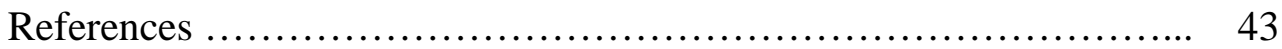


"(...) the notion that what used to be called "contractionary" fiscal policies may in fact be expansionary is fast becoming part of the conventional wisdom (...) Need I point out that the answer to the question of how deficit reduction can stimulate the economy is not just "academic"? It potentially affects the well-being of hundreds of millions of people around the globe. An answer would be a welcome addition to the 'core of practical macroeconomics that we should all believe'" [Blinder (1997, p. 242-243)].

\section{1 - Introduction}

Fiscal policy may have non-Keynesian effects on private consumption and investment decisions. It is therefore relevant to identify the conditions under which a fiscal expansion may either contribute to the increase of economic activity or deploy a recession. The basic underlying idea was already put forward by Feldstein (1982) who stated that permanent public expenses reductions may be expansionist if they are seen as an indication of future tax cuts, giving rise to expectations of a permanent income increase. More recently, for instance Blanchard (1990), Sutherland (1997) and Perotti (1999) argue that there is a higher probability of fiscal policy being non-Keynesian when there is a significant public debt-to-GDP ratio. ${ }^{1}$

The possibility of non-Keynesian effects was first documented by the seminal contribution of Giavazzi and Pagano (1990) who studied the fiscal consolidations that occurred in Denmark in 1983-86 and in Ireland in 1987-89. ${ }^{2}$ The evidence for these two

\footnotetext{
1 "'Perverse" savings reactions are all the more likely if public debt is already high, since the private sector may fear tax increases further down the road to offset a debt explosion," OECD (1999).

${ }^{2}$ The time span of the fiscal consolidation in Ireland varies accordingly with some authors. For instance Barry (1991) and Bradley and Whelan (1997) consider the period 1987-1990, since there was a high real GDP growth rate in that year, even if the budget deficit already started increasing in that year.
} 
countries showed that a contractionary fiscal policy may well be expansionary, when put into practice in a situation of public accounts distress, and co-ordinated with an adequate exchange rate policy. The fiscal episodes of these two countries exemplified also the relevance of the Ricardian equivalence idea. In other words, when an increase of public expenditures casts doubts on the sustainability of fiscal policy and on the level of the debt-to-GDP ratio, one may observe an increase of private saving and a reduction of private consumption. By the opposite reasoning, after a reduction of public spending, fiscal policy may induce an increase in private consumption. This type of theoretical analysis dwells on, therefore, on such topics as Ricardian Equivalence and the sustainability of fiscal policy.

According to Keynesian explanations, budget deficit reductions, after for instance the implementation of spending cuts, would result in a temporary slowdown of aggregate demand and of economic activity. According to a neo-classic explanation, a budget reduction would have no effect on economic activity since aggregate supply is supposed to be the main determinant of economic growth. Keynesian theory postulates that after a fiscal contraction, aggregate demand reduction results both directly, through the decrease in public consumption and investment, and indirectly, when families reduce their consumption as a consequence of a lower disposable income, brought about by the increase of taxes or by the decrease of public transfers. The several fiscal episodes in Europe during the last two decades gave rise to a growing body of both theoretical and empirical literature concerning the so called "non-Keynesian" effects of fiscal policy.

Among several theoretical explanations concerning the existence of nonKeynesian fiscal policy effects, see for instance Blanchard (1990), Bertola and Drazen (1993), Barry and Devereux (1995), Sutherland (1997) and Perotti (1999). This growing literature contributed to challenge the broadly accepted Keynesian notion concerning the existence of a positive fiscal policy multiplier, since the expansionary fiscal contraction possibility may not be discarded lightly. For an overview of the topic see also Perotti (1998) and Alesina, Perotti and Tavares (1998). 
The available empirical work so far doesn't seem to be straightforwardly rejecting the expansionary fiscal contraction hypothesis. Indeed, empirical evidence appears to show that the existence of non-Keynesian effects may well depend upon the size and the persistence of the fiscal adjustment. The composition of the adjustment is also relevant, that is, to what degree is the fiscal contraction based on tax increases, and public investment or consumption cuts. Alesina and Perotti (1995, 1997), Giavazzi and Pagano (1996), McDermott and Wescott (1996), Alesina and Ardagna (1998), Perotti (1999), Giavazzi, Jappelli, and Pagano (2000) and Heylen and Everaert (2000) present empirical results concerning the composition and size determinants of successful adjustments. One of the conclusions that appears throughout many of the empirical papers is that a fiscal consolidation based mostly on spending cuts, rather than tax increases, tends to increase the chances of success.

This paper contributions to the existent literature on fiscal adjustments are first, the suggestion of a theoretical modelling of non-Keynesian effects of fiscal policy; secondly, the statistical determination of fiscal episodes between 1970 and 1999 and the empirical testing of non-Keynesian successful fiscal adjustments for the EU-15 countries.

The organisation of the paper is as follows. Section two briefly reviews the literature on the effects of fiscal policy adjustments. In section three a model with two periods for private consumption is suggested, in order to explain the possibility of both Keynesian and non-Keynesian effects of fiscal policy. Section four discusses the methodological issues of selecting and testing the existence of fiscal episodes. Section five of the paper empirically tests the existence of non-Keynesian effects in the EU-15, covering the period 1970 to 1990 . Section six is a conclusion.

\section{2 - Fiscal policy effects: theoretical issues}

The standard Keynesian effect of fiscal policy on private consumption (C), resulting for instance from an increase in public expenditure $(G)$, is the usual increase of private consumption $(\mathrm{dC} / \mathrm{dG}>0)$. If however, to support the fiscal consolidation, a tax 
(T) cut occurs, the expected impact on private consumption would be a decrease of the families' expenditures $(\mathrm{dC} / \mathrm{dT}<0)$.

The usually assumed positive correlation between private consumption and fiscal expansion may be reversed if some particular conditions are in place. For instance, a significant and sustained reduction of government expenditures may lead consumers to assume that a permanent tax reduction will also take place in the near future. In that case, an increase in permanent income and in private consumption may well occur, generating also better expectations for private investment. ${ }^{3}$ However, if the reduction in expenses is small and temporary, private consumption may not respond positively to the fiscal cut back. In other words, it appears reasonable to assume that under the right conditions, consumers might anticipate the benefits from the fiscal consolidation and act as described above.

Another point that seems to be compelling, is the fact that an increase in public expenditures will have the typical Keynesian effects when the level of public debt or of the budget deficit are small. If a country has an important budget deficit or a very high debt-to-GDP ratio, a fiscal consolidation may well produce the discussed non-Keynesian effects. In general, a public expenditures cut back may have non-Keynesian results when the impact is large enough in order to change future expectations about future budget deficits and public debt evolution. ${ }^{4}$

Blanchard (1990) and Sutherland (1997) sustain that non-Keynesian effects may be associated with tax increases at high levels of government indebtment, while Bertola and Drazen (1993) model the impact of public expenditures as a function of the initial

\footnotetext{
${ }^{3}$ This "non-Keynesian" macroeconomics, related with the consumers' expectations, already made its way into the macroeconomics textbook (see for instance Blanchard (2000)).

${ }^{4}$ Notice however, that even in a simple Keyenesian formulation, with the standard relations, $Y=C+G+I, G=\bar{G}, Y^{d}=Y-T, T=t Y$ and $C=c Y^{d}$, a fiscal policy contraction may lead to an output expansion. In fact, an increase of the budget surplus (through a raise in taxes or due to a cut in public expenses) produces an output increase if the following two conditions are fulfilled: $c<\Delta G / \Delta T<1 /(1-t)$.
} 
level of government expenses. This kind of argument is based on what for instance Zaghini (1999) labels "the expectational view of fiscal policy." In other words, if the fiscal consolidation appears to the public as a serious attempt to reduce the public sector borrowing requirements, there may be an induced wealth effect leading to the increase of private consumption. Also, the reduction of the government borrowing requirements diminishes the risk premium associated with public debt issuance, contributes to reduce real interest rates and allows the crowding-in of private investment. However if consumers don't think that the fiscal consolidation is credible, then the customary negative Keynesian effect on consumption will prevail.

Blanchard (1990) presents a model where the initial level of public debt has an important role for the effects of fiscal policy on private consumption. For instance, the increase in taxes would have two effects: the first effect results from the fact that an increase in taxes, shifts some of the tax burden from future generations to the present generations, and contributes therefore to reduce current private consumption. The second effect would be a positive wealth effect, related to the idea that an increase in taxes today, will avoid an increase of taxes in the future and would also allow to reduce the long term loss of income. A present increase in taxes might therefore be a factor that reduces the uncertainty about the future conduction of fiscal policy. Following this line of reasoning, consumers can then reduce accumulated saving, some of that was probably set up as a precaution to meet future tax increases. This second effect may be the prevailing one, when for instance there is already a high debt-to-GDP ratio.

McDermott and Wescott (1996) also discuss the possibility of a wealth effect as an explanation to the existence of a non-Keynesian transmission channel of fiscal policy. If there are doubts concerning the sustainability of fiscal policy, a fiscal consolidation may be a factor in favour of the reduction of interest rates. This may in turn, help increase the market value of the assets portfolios held by the consumers, and the implicit wealth effect would allow the increase of aggregate demand. 
When there is a small debt-to-GDP ratio, that is, in the absence of a fiscal crisis, an increase of government spending crowds out private consumption because of an expectation of higher future taxes and an expectation that permanent income is indeed lower. If however, public expenses keep rising, beyond a certain limit there will be also an increased probability that a fiscal consolidation might happen (in Bertola and Drazen (1993) words, public expenditures reach a "trigger point" after which an fiscal adjustment is very probable). When the fiscal adjustment occurs, there are expectations that there will be significant future tax cuts, leading therefore to the increase of the consumer's permanent income, the same happens with private consumption, and consumers tend to exhibit a Ricardian behaviour. As Bertola and Drazen (1993, p. 12) put it, "a policy innovation that would be contractionary in a static model may be expansionary if it induces sufficiently expectations of future policy changes in the opposite direction." For instance, Cour et al (1996) maintains that Ricardian behaviour might have been in place during the fiscal consolidations of Denmark and Ireland in the $80 \mathrm{~s} .{ }^{5}$ In fact, an increase in public expenditures, financed by public debt, might put at risk the sustainability of fiscal policy and households would therefore increase private saving.

Sutherland (1997) considers a model where consumers have finite horizons, in such a way that a tax raise reduces private consumption and increases national saving. Along the lines explained by Blanchard (1990), Sutherland also supposes that consumers expect the government to push a fiscal consolidation when the debt-to-GDP ratio goes beyond a given threshold. If the public debt ratio is low, an increase in taxes reduces private consumption. However, when some public debt limit is reached there is a bigger probability that a tax increase may rise private consumption, basically because it postpones the costs of the fiscal consolidation that, with finite-horizon households, will be supported mainly by the future generations. In such a setting, a tax hike could, in a not Keynesian way, increase consumers' inter-temporal income and consumer spending. This might lead to a decrease in private saving that could even be sufficient to offset the increase of public saving and therefore yield a decrease of national saving (assuming for

\footnotetext{
${ }^{5}$ The application of Ricardian equivalence to these two countries is nevertheless contested by Creel (1998).
} 
simplicity sake a closed economy). In other words, when there is a considerable debt-toGDP ratio, there is a higher probability of consumers displaying Ricardian behaviour, maybe assuming there could be a fiscal policy sustainability problem ahead. ${ }^{6}$

Therefore, when there is an important debt-to-GDP ratio, a budget deficit increase, due to the raise of public expenditures, might also have a contractionary effect, a result opposite to the Keynesian explanation. Consumers would have a Keynesian behaviour when the aforementioned ratio is small, but they start acting less and less Keynesian and more in a Ricardian way, when the ratio increases. They simply become more aware of the fact that they are probably not going to succeed in shifting the deficit financing costs to the next generations. In other words, for high levels of debt-to-GDP ratios, the rising uncertainty about the future tax growth path leads consumers to partially switch from Keynesian behaviour to Ricardian behaviour. ${ }^{7}$

Perotti (1999) presents a model to explain the effect of fiscal episodes on private consumption. The underlying assumptions of the model include non lump-sum taxes and the hypotheses that politicians discount more the future than consumers do. In other words, consumers have a perception that the future value of taxes will be higher than its actual value. Still another hypothesis is the existence of some rationed consumers in the economy in such a way that restricted consumers spends their entire disposable income. Also present in the model is the idea that the higher the debt-to-GDP ratio the more likely is the possibility of fiscal policy giving rise to non-Keynesian effects.

Alesina and Perotti $(1995,1997)$ highlight the importance of the composition of the fiscal adjustment. According to the results presented by the authors, for 20 OECD countries, fiscal consolidations characterised by a current expenditure cut have a higher probability of success than those consolidations based on tax increases. Similar

\footnotetext{
${ }^{6}$ Afonso (1999) presented some evidence of Ricardian consumer behaviour for the Euro area. Evidence of unsustainable fiscal policies in the European union may also be found for instance in Athanasios and Sidiropoulos (1999), Uctum and Wickens (2000) and Afonso (2000).

${ }^{7}$ Bhattacharya (1999) argues also along these lines and presents some evidence that households move from non-Ricardian to Ricardian behaviour as the debt-to-GDP reaches high levels.
} 
conclusions are provide by McDermott and Westcott (1996) and by Alesina and Ardagna (1998), while Heylen and Everaert (2000) empirically contest the idea that current expenditures reductions are the best policy to get a successful fiscal consolidation.

Perotti (1996) and Alesina and Perotti (1997) define two types of fiscal adjustment. Type 1 adjustment, when the budget deficit is reduced through cuts in social expenditures (unemployment subsidies, minimum income subsidies) and cuts in the public sector wages; Type 2 adjustment, when the budget deficit is reduced with the increase of taxes on labour income and with cuts in public investment expenditures. Indeed, according to Alesina and Perotti (1997), for instance the fiscal episode of Ireland in 1987-1989 was a Type 1 adjustment while the 1983-1986 fiscal episode in Denmark could be classified as a Type 2 adjustment.

Finally, Giavazzi and Pagano (1990) and Alesina and Perroti (1997) stress the role of exchange rates in promoting successful fiscal adjustments, since a significant exchange rate depreciation occurred before and during the fiscal consolidations of Ireland and Denmark in the 80 s. $^{8}$

\section{3 - A theoretical model for fiscal policy non-Keynesian effects}

The purpose of this section is to present a theoretical formulation in order to explain the possibility of both Keynesian and non-Keynesian effects of fiscal policy, the main feature being the relation between interest rate and taxes and the existence of rationed consumers.

Suppose a model with two periods, period 1 and period 2, for a small economy, with income in each year given by

\footnotetext{
${ }^{8}$ Dornbusch (1989), Giavazzi and Pagano (1990), Whelan (1991), Leibfritz, Roseveare and van den Noord (1994), Artus (1996), Giavazzi and Pagano (1996), McDermott and Westcott (1996), Bergman and Hutchison (1997) and Creel (1998) also analyse these fiscal episodes.
} 
$Y_{1}=C_{1}+\bar{G}_{1}+I_{1}$

$Y_{2}=C_{2}+\bar{G}_{2}+I_{2}$,

where $Y_{i}$ is the income; $C_{i}$ private consumption; $G_{i}$ public expenditures, assumed to be exogenous and $I_{i}$ investment, with $\mathrm{i}=1,2$.

The domestic interest rate, $r$, depends on the foreign interest rate, $r^{*}$, and it should also reflect the country specific risk conditions, which may be seen as related to the public receipts the government has available to finance its budgetary needs. ${ }^{9}$ In other words, the less significant those public revenues are, the more the government must find credit in the capital markets, paying therefore higher interest rates. The internal interest rate could then be seen as a positive function of the budget deficit or, alternatively, as a decreasing function of the tax revenues.

For instance Artus (1997) observes that the European countries with the bigger interest rate differentials with reference to Germany, are the countries with the more significant budget deficits. Also, Cebula (1997) finds empirical evidence for the US that budget deficits have a significant and positive effect on the public debt long run interest rates. ${ }^{10}$ Therefore, an interest rate reduction would rise the market value of the assets owned by the families. If this wealth effect is higher than the negative effect that the fiscal consolidation has on aggregate demand, then the fiscal contraction may result in a net increase of private consumption. ${ }^{11}$

\footnotetext{
${ }^{9} \mathrm{McDermott}$ and Westcott (1996) state that fiscal contractions (for instance an increase of public revenues) contribute to lower the interest rate risk premium and to increase investment.

${ }^{10}$ Ibrahim and Kumah (1997) also find some evidence that an increase in the budget deficit leads to an increase of the short run interest rate differential, vis-à-vis the US, in the UK, Japan and Sweden. See also Rose and Hakes (1995) concerning the relationship between deficits and interest rates.

${ }^{11}$ Perotti (1998) uses also this argument.
} 
It is interesting to notice that for instance in the fiscal consolidation of Denmark in the period 1983-1986, public revenues increased from 49,8 percent of GDP in 1982 to 56,9 percent in 1987 . With more detail, it is possible to recognise that taxes on income and wealth increased from 24,9 percent to 29,2 per cent of GDP in 1987. At the same time, and during the same period, it is easy to confirm that the long run interest rate diminished from 20,5 percent in 1982 to 11,9 percent in 1987.

One may then assume the existence of a negative link relation between the domestic interest rate and public revenues, or, to put in another way, a negative link between domestic interest rate and taxes, with the interest rate given by

$r=r^{*}+k\left(T_{1}\right)$

where $r^{*}$ is the foreign interest rate and $T_{1}$ the tax revenues, with $\partial r / \partial T_{1}<0$.

In each period the government fulfils its budget constraint, that can be written respectively for period 1 and period 2 as

$T_{1}+B_{1}=\bar{G}_{1}$

$T_{2}+B_{2}-B_{1}=\bar{G}_{2}$

where $\mathrm{B}_{2}$ is a certain final value for the stock of public debt.

The government inter-temporal budget constraint, in this model with two periods, may be written as

$T_{1}+B_{1}+\frac{T_{2}}{1+r}+\frac{B_{2}}{1+r}-B_{1}=\bar{G}_{1}+\frac{\bar{G}_{2}}{1+r}$ 
$T_{1}+\frac{T_{2}}{1+r}+\frac{B_{2}}{1+r}=\bar{G}_{1}+\frac{\bar{G}_{2}}{1+r}$.

Private consumption is then a function of present and future disposable income. Presuming also there is a certain fraction of consumers, $\lambda$, that face liquidity constraints, that is, they consume in each period their entire disposable income, consumption in period 1 is given by

$C_{1}=\lambda\left(Y_{1}-T_{1}\right)+(1-\lambda) \frac{1}{1+\rho}\left[Y_{1}-T_{1}+\left(Y_{2}-T_{2}\right) \frac{1}{1+r}\right]$

with $0<\lambda<1$ and where $\rho$ is a discount rate that measures the preference for consumption between the two periods.

The effect on private consumption of a tax increase may be derived as

$\frac{\partial C_{1}}{\partial T_{1}}=-\lambda+\left(\frac{1-\lambda}{1+\rho}\right)\left\{-1+\frac{\left[\frac{\partial Y_{2}}{\partial T_{1}}-\frac{\partial T_{2}}{\partial T_{1}}\right](1+r)-\left(Y_{2}-T_{2}\right) \frac{\partial r}{\partial T_{1}}}{(1+r)^{2}}\right\}$

and noticing that $\partial T_{2} / \partial T_{1}=-(1+r)$, it is possible to write ${ }^{12}$

$$
\frac{\partial C_{1}}{\partial T_{1}}=-\lambda+\left(\frac{1-\lambda}{1+\rho}\right)\left(\frac{\partial r}{\partial T_{1}}\right)\left[\frac{1}{1+r} \frac{\partial Y_{2}}{\partial I_{2}} \frac{\partial I_{2}}{\partial r}-\frac{Y_{2}-T_{2}}{(1+r)^{2}}\right]
$$

Observe that the second term of the right hand side of the previous equation has a positive sign,

\footnotetext{
${ }^{12}$ See Appendix A.
} 


$$
\frac{\partial C_{1}}{\partial T_{1}}=-\lambda+\underbrace{\left(\frac{1-\lambda}{1+\rho}\right)}_{(+)} \underbrace{\left(\frac{\partial r}{\partial T_{1}}\right)}_{(-)} \underbrace{[\frac{1}{1+r} \underbrace{\frac{\partial Y_{2}}{\partial I_{2}} \frac{\partial I_{2}}{\partial r}}_{(+)}-\underbrace{\frac{Y_{2}-T_{2}}{(1+r)^{2}}}_{(-)} \underbrace{(1+)}_{(+)}]}_{(-)}
$$

so that the sign of the derivative $\partial C_{1} / \partial T_{1}$ is undetermined, giving therefore rise to the possibility for the existence of fiscal policy non-Keynesian effects on private consumption.

In fact, and defining

$z=\left(\frac{1-\lambda}{1+\rho}\right)\left(\frac{\partial r}{\partial T_{1}}\right)\left[\frac{1}{1+r} \frac{\partial Y_{2}}{\partial I_{2}} \frac{\partial I_{2}}{\partial r}-\frac{Y_{2}-T_{2}}{(1+r)^{2}}\right]$

it is possible to write more concisely

$$
\frac{\partial C_{1}}{\partial T_{1}}=-\lambda+z
$$

and then, according to the magnitude of the $z$ term, a tax increase may produce either a private consumption increase, the case where $|z|>|\lambda|$, or the usual Keynesian effect of decreasing private consumption, the case where $|z|<|\lambda|$.

The previous result immediately allows some conclusions:

i) There won't be non-Keynesian fiscal policy effects when $\partial r / \partial T_{1}=0$;

ii) If all consumers are rationed, $\lambda=1$, fiscal policy will have the usual Keynesian effects; 
iii) The bigger the proportion of non-rationed consumers (the lower the $\lambda$ ) the bigger the probability for the occurrence of non-Keynesian effects;

iv) When the interest rate is more responsive to changes in public revenues, a high value for $\left|\partial r / \partial T_{1}\right|$, more likely is the existence of non-Keynesian effects.

The effects on income, of a change in tax revenues, may also be obtained through the computation of

$\frac{\partial Y_{1}}{\partial T_{1}}=\frac{\partial C_{1}}{\partial T_{1}}+\frac{\partial I_{1}}{\partial T_{1}}$

Considering that we have

$\frac{\partial I_{1}}{\partial T_{1}}=\frac{\partial I_{1}}{\partial r} \frac{\partial r}{\partial T_{1}}$

it is possible to substitute (9) and (12) into (11) in order to obtain

$\frac{\partial Y_{1}}{\partial T_{1}}=-\lambda+\left(\frac{1-\lambda}{1+\rho}\right)\left(\frac{\partial r}{\partial T_{1}}\right)\left[\frac{1}{1+r} \frac{\partial Y_{2}}{\partial I_{2}} \frac{\partial I_{2}}{\partial r}-\frac{Y_{2}-T_{2}}{(1+r)^{2}}\right]+\frac{\partial I_{1}}{\partial r} \frac{\partial r}{\partial T_{1}}$

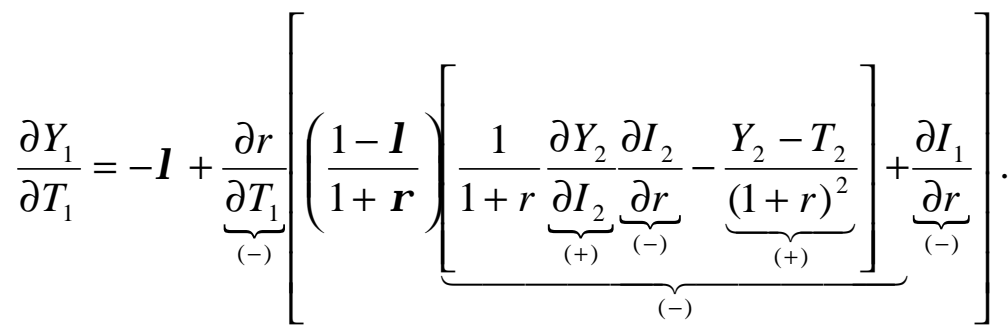

Using $w$ as a notation for the second term of the last equation right hand side, it is possible to write 
$\frac{\partial Y_{1}}{\partial T_{1}}=-\lambda+w$

and to realise that we have $\partial Y_{1} / \partial T_{1}>0$, the non-Keynesian effect, as a feasible result, when $|w|>|\lambda|$, being the previous conclusions concerning private consumption also applicable in this case.

\section{4 - A brief review of the empirical literature}

\section{1 - How to define "fiscal expansion/contraction"?}

A critical point when assessing the existence of non-Keynesian effects of fiscal policy, is the choice of the measure of fiscal adjustments. The empirical literature uses several definitions for timing fiscal contractions, relying essentially on the structural budget balance concept, the balance that would arise if both expenditures and taxes were determined by potential rather than actual output. ${ }^{13}$ If the structural budget does not allow the correction of all the effects on budget balance, resulting from changes in economic activity such as inflation or real interest rate changes (as noted by Blanchard [1993]). In order to try to exclude some of those effects, the usually adopted measure turns out to be the primary structural budget balance. This measure is used either as percentage of GDP or as a percentage of potential output (see for instance Giavazzi and Pagano [1996], Cour et al. [1996] and McDermott and Wescott [1996]).

An attempt at statistically determining fiscal episodes is performed in this section. The key variable used is the structural adjusted primary balance, and the fiscal policy

\footnotetext{
${ }^{13}$ The several methods of computing structural budget balances are described namely by Barrel, Morgan, Sefton and in' t Veld (1994), Brandner, Diebalek and Schuberth (1998). For more detailed references for the OECD method see Giorno, Richardson, Roseveare and van den Noord (1995), for the EU method, EC (1995) and for the IMF method, IMF (1993, 1995). For discussions concerning the calculation of potential output see also Ongena and Roger (1997) and Giorno and Suyker (1997). Heller, Haas and Mansur (1986) and Blejer and Cheasty (1991) provide a review of the fiscal impulse measure. Blanchard (1993) suggests an alternative method to compute structural budget balances, the so-called Blanchard Fiscal Impulse.
} 
episodes determined by this methodology capture well known fiscal adjustments in Europe in the 80s and 90s (e.g. Ireland, Denmark, Sweden).

The use of the structural budget balance, instead of the primary structural budget balance, would have the advantage of using information concerning the fact that the existence of high level of interest expenditures, may well mean that a fiscal contraction is quite plausible in the short term, as a requisite to reduce budgetary imbalances. In practice, the differences between using the structural budget deficit or the primary structural budget deficit to determine the fiscal episodes are not very significant. For instance, calculations made by Cour et al. (1996), using the primary structural budget balance, and by the OECD (1996), using the structural budget balance, with the same data base, find practically the same fiscal episodes for the several OECD countries.

Besides the choice of the budget measure, there are also differences in the literature as how to define the period of a fiscal contraction or expansion. According to the chosen definition, the number of fiscal episodes changes as well as the turning points of fiscal policy (the "trigger points" in Bertola and Drazen [1993] words).

The fiscal episode definition adopted for instance by Alesina and Ardagna (1998) allows that some stabilisation periods may have only one year. Whereas the definition used by Giavazzi and Pagano (1996), decrease the probability of a one-year fiscal adjustment periods by using a limit of 3 percentage points of GDP for a single year consolidation. However, the above definitions, by choosing arbitrarily 2 or 3 years fiscal adjustment periods, end up determining the number of years subjectively. In other words, this kind of methodology for selecting the time span of fiscal episodes, may either lead to an excessive number of periods or to neglect single year length fiscal episodes.

Table 1 identifies several measures used in the literature to determine the periods of fiscal consolidation 
Table 1 - Fiscal policy measures and the determination of fiscal episodes

\begin{tabular}{|c|c|c|}
\hline Author and date & The determination of fiscal consolidations & $\begin{array}{c}\text { Method for } \\
\text { structural } \\
\text { budget }\end{array}$ \\
\hline $\begin{array}{l}\text { Alesina and } \\
\text { Perotti (1995) }\end{array}$ & $\begin{array}{l}\text { Definition 1: years where the change of the primary } \\
\text { structural balance exceeds } 1,5 \text { percent of GDP; } \\
\text { Definition 2: years where the change of the primary } \\
\text { structural balance deviates from the country average } \\
\text { change by }+/-1 \text { standard deviation. }\end{array}$ & $\begin{array}{l}\text { Blanchard } \\
\text { fiscal } \\
\text { impulse }\end{array}$ \\
\hline $\begin{array}{l}\text { McDermott and } \\
\text { Wescott (1996) }\end{array}$ & $\begin{array}{l}\text { The primary structural government balance must increase } \\
\text { by at least } 1,5 \text { percent of potential GDP over two years } \\
\text { and not decrease in either of the two years. }\end{array}$ & OECD, IMF \\
\hline Cour et al (1996) & $\begin{array}{l}\text { Three-year period, during which there is a change in the } \\
\text { primary structural budget balance of at least } 3 \text { percent of } \\
\text { GDP. }\end{array}$ & OECD \\
\hline De Ménil (1996) & $\begin{array}{l}\text { Years where the change of the primary structural balance } \\
\text { exceeds } 1,5 \text { percent of GDP. }\end{array}$ & $\begin{array}{l}\text { Blanchard } \\
\text { fiscal } \\
\text { impulse }\end{array}$ \\
\hline OECD (1996) & $\begin{array}{l}\text { There is a change of at least } 3 \text { percent of GDP in the } \\
\text { structural budget balance, in consecutive years. }\end{array}$ & OECD \\
\hline IMF $(1993,1995)$ & $\begin{array}{l}\text { Two years period, during which there is a change in the } \\
\text { structural budget balance of at least } 1,5 \text { percentage points } \\
\text { of GDP. }\end{array}$ & IMF \\
\hline $\begin{array}{l}\text { Giavazzi and } \\
\text { Pagano (1996) }\end{array}$ & $\begin{array}{l}\text { The accumulated change in the primary structural deficit } \\
\text { is above } 5,4 \text { and } 3 \text { percentage points of GDP respectively } \\
\text { in four, three and two consecutive years or the change is } \\
\text { of } 3 \text { percentage points of potential GDP in one single } \\
\text { year. }\end{array}$ & OECD \\
\hline $\begin{array}{l}\text { Alesina and } \\
\text { Perotti (1997) }\end{array}$ & $\begin{array}{l}\text { Fiscal contraction: a one year period, where the primary } \\
\text { structural balance decreases by at least } 1,5 \text { percent of GDP } \\
\text { or a two year period where the primary structural balance } \\
\text { decreases at least } 1,25 \text { per cent of GDP. }\end{array}$ & $\begin{array}{l}\text { Blanchard } \\
\text { fiscal } \\
\text { impulse }\end{array}$ \\
\hline $\begin{array}{l}\text { Missale, Giavazzi } \\
\text { and Benigno } \\
(1997)\end{array}$ & $\begin{array}{l}\text { Periods of one or more years where the primary structural } \\
\text { balance increases at least one percentage point of GDP. }\end{array}$ & OECD \\
\hline $\begin{array}{l}\text { Alesina and } \\
\text { Ardagna (1998) }\end{array}$ & $\begin{array}{l}\text { The primary structural balance increases at least } 2 \\
\text { percentage points of GDP, in one year, or, increases } 1,5 \\
\text { percentage points of GDP on average in two consecutive } \\
\text { years. }\end{array}$ & $\begin{array}{l}\text { Blanchard } \\
\text { fiscal } \\
\text { impulse }\end{array}$ \\
\hline Zaghini (1998) & $\begin{array}{l}\text { The cyclically adjusted primary budget deficit changes } \\
\text { above a given threshold. }\end{array}$ & EC \\
\hline $\begin{array}{l}\text { Miller and Russek } \\
\text { (1999) }\end{array}$ & $\begin{array}{l}\text { A trigger point exists when the key variable (debt-to-GDP } \\
\text { ratio, cyclically adjusted primary deficit) in a given year, } \\
\text { exceeds its mean plus one standard deviation. }\end{array}$ & OECD \\
\hline $\begin{array}{l}\text { Giavazzi, Jappelli } \\
\text { and Pagano } \\
(2000)\end{array}$ & $\begin{array}{l}\text { A large and persistent fiscal expansion or contraction is } \\
\text { defined as an episode in which the ratio of full- } \\
\text { employment surplus to potential output changes by more } \\
\text { than } 1,5 \text { percent per year over a two-year period. }\end{array}$ & OECD \\
\hline
\end{tabular}




\section{2 - Empirical tests}

Previous papers had already discussed and tested the effects of fiscal policy on private consumption, namely Feldstein (1982), Modigliani and Sterling (1986, 1990), Kormendi and Meguire (1990). Kormendi and Meguire (1990) present a statistically significant estimate of $-0,25$ for the public expenditure coefficient in the private consumption function, defiantly not a Keynesian result.

The first empirical tests, concerning non-Keynesian effects of fiscal policy, were performed by Giavazzi e Pagano $(1990,1996)$ with data for Denmark, Ireland and Sweden. In those countries there was evidence relating fiscal consolidations and positive private consumption' growth rates, either after the decrease of public expenditures or the increase of taxes. As the two main reasons to explain the effects of fiscal consolidations Giavazzi and Pagano (1996) present both the persistence and the credibility of the consolidations and also the fact that there was already a high debt-to-GDP ratio when the fiscal episode took place.

After the tests for Ireland and Denmark, Giavazzi and Pagano (1996) estimated several reaction functions for the OCDE countries, in order to search for non-Keynesian effects of fiscal policy. According to their results, for an accumulated change in the primary structural budget balance, bellow 5 percent of potential GDP, there is a positive relation between public consumption and private consumption. When the fiscal consolidation goes beyond 5 percent of potential GDP, that relation is reversed, even if not in a symmetrical way. Giavazzi et al. (2000) estimate reaction functions for national saving for the OECD countries and for developing countries, in order to assess the effects of fiscal policy on aggregate saving.

Table 2 summarises some of the empirical evidence found in the literature, concerning the existence of non-Keynesian effects of fiscal policy. 
Table 2 - Empirical evidence of non-Keynesian effects of fiscal policy

\begin{tabular}{|c|c|c|c|c|}
\hline $\begin{array}{l}\text { Author } \\
\text { and date }\end{array}$ & $\begin{array}{l}\text { Period and } \\
\text { country }\end{array}$ & Test performed & $\begin{array}{l}\text { Method } \\
\text { used }\end{array}$ & Results \\
\hline $\begin{array}{l}\text { Giavazzi } \\
\text { and Pagano } \\
(1990)\end{array}$ & $\begin{array}{l}\text { 10 OECD countries } \\
(1973-1989) \\
\text { Ireland } \\
(1961-1987) \\
\text { Denmark } \\
(1971-1987)\end{array}$ & $\begin{array}{l}\text { Effect of fiscal } \\
\text { contractions on } \\
\text { private } \\
\text { consumption }\end{array}$ & OLS & $\begin{array}{l}\text { Public spending cuts increase } \\
\text { private consumption }\end{array}$ \\
\hline $\begin{array}{l}\text { de Ménil } \\
\text { (1996) }\end{array}$ & $\begin{array}{l}\text { OECD countries } \\
(1960-1992)\end{array}$ & $\begin{array}{l}\text { Effect on } \\
\text { consumption of } \\
\text { public expenditures } \\
\text { increase }\end{array}$ & OLS & $\begin{array}{l}\text { Keynesian effects in } \\
\text { countries in countries where } \\
\text { consumers are not } \\
\text { constrained; null multipliers } \\
\text { in countries without liquidity } \\
\text { restrictions }\end{array}$ \\
\hline $\begin{array}{l}\text { Giavazzi } \\
\text { and Pagano } \\
(1996)\end{array}$ & $\begin{array}{l}\text { OECD countries } \\
(1976-1992)\end{array}$ & $\begin{array}{l}\text { Effect on } \\
\text { consumption of } \\
\text { budget deficit } \\
\text { increase }\end{array}$ & $\begin{array}{l}\text { OLS, } \\
\text { 2SLS }\end{array}$ & $\begin{array}{l}\text { There are non-Keynesian } \\
\text { effects from public spending } \\
\text { and taxes }\end{array}$ \\
\hline $\begin{array}{l}\text { McDermott } \\
\text { and } \\
\text { Westcott } \\
(1996)\end{array}$ & $\begin{array}{l}\text { OECD countries } \\
(1960-1994)\end{array}$ & $\begin{array}{l}\text { Probability that a } \\
\text { fiscal episode } \\
\text { decreases the debt- } \\
\text { to-GDP ratio in } \\
\text { more than } 3 \\
\text { percentage points }\end{array}$ & $\begin{array}{l}\text { Logit } \\
\text { model }\end{array}$ & $\begin{array}{l}\text { There is a higher probability } \\
\text { that a decrease in } \\
\text { expenditures reduces the } \\
\text { debt-to-GDP ratio than an } \\
\text { increase of taxes }\end{array}$ \\
\hline $\begin{array}{l}\text { Alesina and } \\
\text { Ardagna } \\
(1998)\end{array}$ & $\begin{array}{l}\text { OECD countries } \\
(1960-1994)\end{array}$ & $\begin{array}{l}\text { Probability of } \\
\text { success of a fiscal } \\
\text { contraction }\end{array}$ & $\begin{array}{l}\text { Probit } \\
\text { model }\end{array}$ & $\begin{array}{l}\text { A fiscal contraction through } \\
\text { expenditures cuts is } \\
\text { expansionary }\end{array}$ \\
\hline $\begin{array}{l}\text { Zaghini } \\
\text { (1998) }\end{array}$ & $\begin{array}{l}\text { UE countries } \\
(1970-1998)\end{array}$ & $\begin{array}{l}\text { Probability of } \\
\text { success of a fiscal } \\
\text { contraction }\end{array}$ & $\begin{array}{l}\text { Probit } \\
\text { model }\end{array}$ & $\begin{array}{l}\text { Fiscal contractions with } \\
\text { expenditures cuts are more } \\
\text { successful }\end{array}$ \\
\hline $\begin{array}{l}\text { Perroti } \\
(1999)\end{array}$ & $\begin{array}{l}\text { OECD countries } \\
(1965-1994)\end{array}$ & $\begin{array}{l}\text { Effect on private } \\
\text { consumption of a } \\
\text { budget deficit } \\
\text { increase }\end{array}$ & & $\begin{array}{l}\text { The bigger the debt-to-GDP } \\
\text { ratio the more likely is that } \\
\text { the fiscal consolidation turns } \\
\text { out to be expansionist }\end{array}$ \\
\hline $\begin{array}{l}\text { Miller and } \\
\text { Russek } \\
\text { (1999) }\end{array}$ & $\begin{array}{l}\text { 19 OECD countries } \\
(1970-1996)\end{array}$ & $\begin{array}{l}\text { Effect on private } \\
\text { consumption of a } \\
\text { budget deficit } \\
\text { increase }\end{array}$ & $\begin{array}{l}\text { OLS } \\
\text { pooled } \\
\text { regression }\end{array}$ & $\begin{array}{l}\text { Some evidence of non- } \\
\text { Keynesian effects }\end{array}$ \\
\hline \begin{tabular}{l|} 
Giavazzi, \\
Jappelli and \\
Pagano \\
$(2000)$
\end{tabular} & $\begin{array}{l}\text { OECD countries } \\
\text { (1973-1996); } \\
\text { Developing } \\
\text { countries } \\
(1960-1995)\end{array}$ & $\begin{array}{l}\text { Effect on national } \\
\text { saving of fiscal } \\
\text { stimulus }\end{array}$ & $\begin{array}{l}\text { OLS with } \\
\text { fixed } \\
\text { effects }\end{array}$ & $\begin{array}{l}\text { Fiscal contractions are } \\
\text { expansionary when based on } \\
\text { tax increases instead of } \\
\text { spending cuts }\end{array}$ \\
\hline $\begin{array}{l}\text { Heylen and } \\
\text { Everaert } \\
(2000)\end{array}$ & $\begin{array}{l}\text { OECD countries } \\
(1975-1995)\end{array}$ & $\begin{array}{l}\text { Effect on the debt- } \\
\text { to-GDP ratio of } \\
\text { budget components }\end{array}$ & OLS & Inconclusive \\
\hline
\end{tabular}


The relevance of the composition of fiscal adjustments, for the success of a fiscal consolidation, is studied by McDermott and Westcott (1996), with a Logit model for the OECD countries. In a similar approach, Alesina and Ardagna (1998) use Probit models to evaluate the success of a fiscal contraction. In this case, the success of a fiscal contraction is defined as follows: in the 3 years after the fiscal episode, the primary structural budget balance should be, on average, 2 percentage points of GDP bellow the value observed in the year were the fiscal contraction took place. Alternatively, 3 years after the adjustment, the debt-to-GDP ratio must be 5 percentage points of GDP, bellow the level observed in the year of the consolidation.

\section{5 - Non-Keynesian effects in the EU-15}

\section{1 - Fiscal episodes in the EU-15}

In an effort to identify fiscal policy episodes in the UE-15, a simple statistical approach is used, trying also to avoid ad-hoc definitions of fiscal episodes. Annual data for the 15 UE countries, over the period 1961 to 1999, was collected for structural budget balance, computed by the European Commission. ${ }^{14}$ Therefore, our first measure of fiscal impulse is the first difference of the structural budget balance, as a percentage of GDP.

With 487 annual observations, for the 15 countries group, it was possible to calculate for the change in the structural budget balance, an average value of - $-0,005$ and a standard deviation of 1,608. It is also possible to visualise, with the help of a histogram, the possible approximation of a normal distribution to actual data. Figure 1 presents such an approximation with class intervals of 0,125 percent of GDP for the changes in the structural budget balance.

\footnotetext{
${ }^{14}$ A precise description of the data is given in the Appendix B. As far as the author can tell, besides this paper, until now only Zaghini (1999) used the structural balance measure of the EC for the purpose of defining fiscal episodes.
} 
Figure 1 - Changes of the structural budget balance, with class intervals of 0,125 percent of GDP $v s$. a normal distribution (UE-15, 1961-1999)

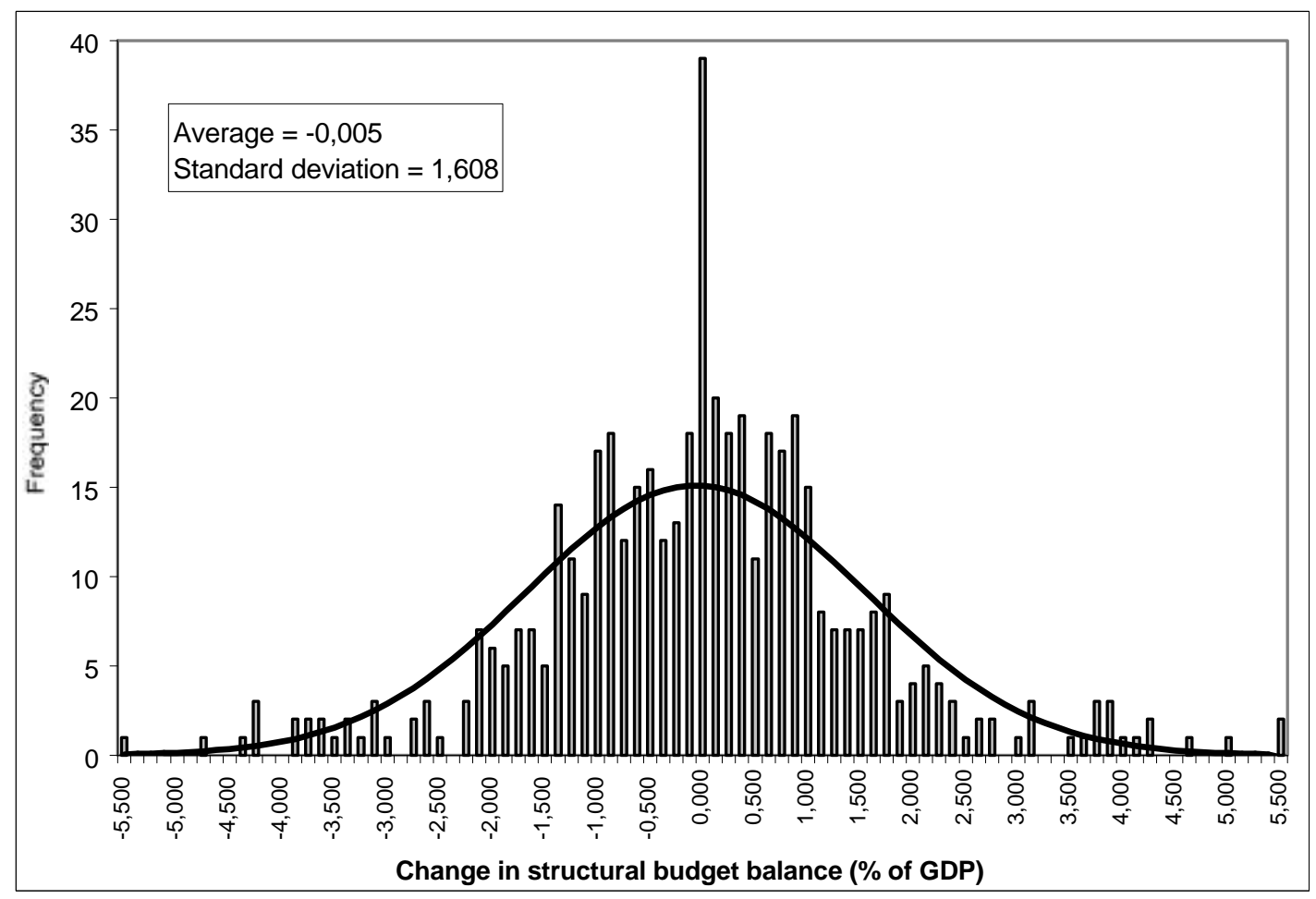

However, and since the structural budget balance comprises the interest on public debt, a component of the budget that the government is unable to influence significantly in the short term, the primary structural budget balance ends up being a better measure of fiscal impulse. For that reason, identical calculations were performed for the annual change of the primary structural budget balance, and the results show an average of 0,075 and a standard deviation of 1,747 . The histogram for the changes of the primary structural budget balance, once again with class intervals of 0,125 percent of GDP, is presented in Figure 2. 
Figure 2 - Changes of the primary structural budget balance, with class intervals of 0,125 percent of GDP vs. a normal distribution (UE-15, 1961-1999)

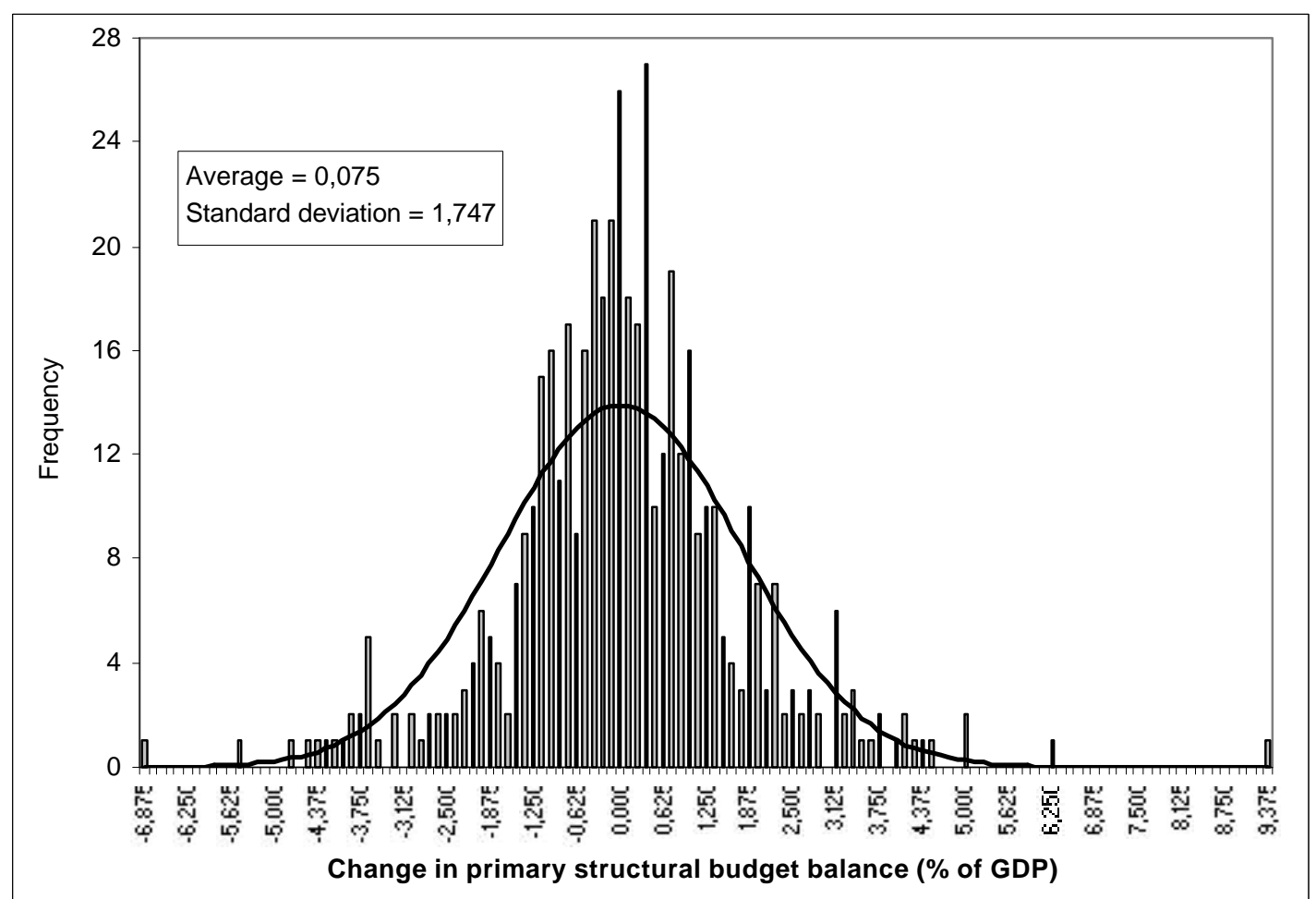

According to both pictures, the differences between the use of the global structural budget balance or the primary structural budget balance do not seem to be very significant. The annual changes of the two fiscal measures were then tentatively divided into six categories, taking into account the following limits: the average value plus or minus one standard deviation and the average value plus or minus one half of on standard deviation. Table 3 shows those limits, using for the structural budget balance the values of $-0,005$ for the mean and 1,608 for the standard deviation, and the for the primary structural budget balance the values of 0,075 for the mean and 1,747 for the standard deviation. 
Table 3 - Categories for the change in the global and primary structural budget balances, as a percentage of GDP, in the EU-15 countries (1961-1999)

\begin{tabular}{|c|c|c|c|}
\hline \multirow{2}{*}{ Intervals } & \multicolumn{2}{|c|}{ Limits } & Fiscal policy \\
\cline { 2 - 3 } & $\begin{array}{c}\text { Structural budget } \\
\text { balance } \\
\boldsymbol{\mu}=\mathbf{- 0 , 0 0 5} \text { and } \\
\boldsymbol{\sigma = 1 , 6 0 8}\end{array}$ & $\begin{array}{c}\text { Primary structural } \\
\text { budget balance } \\
\boldsymbol{\mu}=\mathbf{0 , 0 7 5} \text { and } \\
\boldsymbol{\sigma}=\mathbf{1 , 7 4 7}\end{array}$ & \\
\hline$]-\infty ; \mu-\sigma]$ & ]$-\infty ;-1,61]$ & $-\infty ;-1,67]$ & Highly expansionist \\
]$\mu-\sigma ; \mu-\sigma / 2]$ & ]$-1,61 ;-0,81]$ & $-1,67 ;-0,80]$ & Expansionist \\
]$\mu-\sigma / 2 ; \mu]$ & ]$-0,81 ; 0]$ & ]$-0,80 ; 0,07]$ & Neutral \\
]$\mu ; \mu+\sigma / 2]$ & ] $0 ; 0,8]$ & ] $0,07 ; 0,95]$ & Neutral \\
]$\mu+\sigma / 2 ; \mu+\sigma]$ & ] $0,8 ; 1,6]$ & ] $0,95 ; 1,82]$ & Contractionist \\
]$\mu+\sigma ;+\infty]$ & ] $1,6 ;+\infty]$ & ] $1,82 ;+\infty]$ & Highly contractionist \\
\hline
\end{tabular}

Using the limits given in Table 3, one may then try to present a definition of fiscal episodes, that is, a definition for a period where fiscal policy might be considered either expansionist or contractionist:

i) When the change in the primary structural budget balance is more than one standard deviation in a single year or;

ii) When the annual average change in the primary structural budget balance is at least one half of one standard deviation in the last two years. ${ }^{15}$

With the above definitions, we take into account the first and the second intervals of Table 3, which stand for the existence of either a very expansionist or an expansionist fiscal policy. The fifth and the sixth intervals are also relevant, which signal the occurrence of either a contractionist or a very contractionist fiscal policy. The two intermediary intervals, the third and the fourth, may be seen as indicating changes in the

\footnotetext{
${ }^{15}$ Miller and Russek (1999) and Zaghini (1999) use some similar measures to determine trigger points and fiscal episodes.
} 
structural budget balances that result from the "normal" conduction of fiscal policy, without the character of a significant fiscal adjustment, the relevant issue in this context.

Table 4 identifies the fiscal episodes in the UE-15 countries, according with proposed definitions, and using the change in the primary structural budget balance.

Table 4 - Summary of fiscal episodes in the EU-15, using the primary structural budget balance

\begin{tabular}{|l|c|c|c|}
\hline & Observations & Mean (\%) & $\begin{array}{c}\text { Standard } \\
\text { deviation (\%) }\end{array}$ \\
\hline Total & 487 & 0.075 & 1.747 \\
\hline Fiscal policy episodes & 85 & 1.201 & 0.429 \\
\hline Contractionist (*) (A) & 78 & -0.959 & 0.390 \\
\hline Expansionist (**) (B) & 163 & 0.211 & 2.795 \\
\hline Total of episodes (A)+(B) & 65 & 2.976 & 1.264 \\
\hline Highly contractionist (C) & 54 & -2.963 & 1.093 \\
\hline Highly expansionist (D) & 119 & 0.281 & 3.196 \\
\hline Total of extreme episodes (C) + (D) & &
\end{tabular}

(*) Includes the highly contractionist episodes.

$(* *)$ Includes the highly expansionist episodes.

The 119 more important episodes (65 very contractionist and 54 very expansionist), that is, those episodes where the change in the primary structural budget balance is higher than one standard deviation in only one year, are identified in Table 5. It is worth noticing that the fiscal episodes include the well know expansionary fiscal contractions of Denmark in 1983-84, of Ireland in 1987-88 and also the fiscal expansion of Sweden in 1991-92. 
Table 5 - Fiscal episodes where the change in the primary structural budget balance exceeds (in absolute value) one standard deviation in one year

\begin{tabular}{|l|l|l|}
\hline \multirow{2}{*}{ Country } & \multicolumn{2}{|c|}{ Fiscal episode } \\
\cline { 2 - 3 } & \multicolumn{1}{|c|}{ Very expansionist } & \multicolumn{1}{|c|}{ Very contractionist } \\
\hline Austria & 1975 & 1984,1997 \\
\hline Belgium & $1972,1976,1980$ & $1982,1984,1993$ \\
\hline Denmark & $1975,1982,1987$ & $1983-84,1986,1999$ \\
\hline Finland & $1963,1969,1972,1978-79,1982-83$, & $1966-68,1971,1975-76,1981,1984$, \\
& $1987,1991-92$ & $1988,1998-99$ \\
\hline France & & 1996 \\
\hline Germany & $1965,1975,1990$ & 1982 \\
\hline Greece & $1975,1981,1985$ & $1962,1974,1982,1986-87,1991,1994$, \\
& & 1996 \\
\hline Ireland & $1974-75,1978,1990,1995$ & $1976,1983,1988,1993-94$ \\
\hline Italy & & $1976,1982,1991-94,1997$ \\
\hline Luxembourg & $1972,1979,1986$ & $1982-83,1985$ \\
\hline Netherlands & 1986,1989 & $1977,1991,1993,1996$ \\
\hline Portugal & $1972,1974,1976,1980-81,1993$ & $1982-83,1986,1992,1995$ \\
\hline Spain & 1988 & $1986,1992,1996$ \\
\hline Sweden & $1974,1978-79,1988,1991-92,1999$ & $1971,1976,1983,1987,1995-96,1998$ \\
\hline United Kingdom & $1972-73,1978,1983,1992$ & $1969,1980-81,1998$ \\
\hline
\end{tabular}

\section{2 - Estimation of non-Keynesian fiscal effects in the EU-15}

In order to assess the existence of non-Keynesian effects in the EU-15, the following reaction function, for the annual real growth rate of private consumption, may be used as a starting point:

$$
c_{t}=a_{0}+a_{1} y_{t}+\left(\alpha_{1} \Delta g_{t}+\beta_{1} \Delta \tau_{t}\right)+d_{t}\left(\alpha_{2} \Delta g_{t}+\beta_{2} \Delta \tau_{t}\right)
$$


where $c$ is the real growth rate of private consumption; $y$ the real growth rate of output; $\tau$ and $g$ are respectively the public revenues and expenditures as a percentage of GDP and d an artificial variable, assuming the following values: $d=1$ when there are fiscal adjustments as defined in the previous section and $d=0$ when those fiscal adjustments do not occur.

Theoretically one would expect, in the absence of fiscal episodes, the usual Keynesian effects, that is, a positive effect of public expenditures on private consumption decisions, $\alpha_{1}>0$, and a negative effect of public revenues on private consumption, $\beta_{1}<0$. However, if the expansionary fiscal consolidation hypothesis is valid, the standard Keynesian effects might be reversed, in other words one may observe $\alpha_{2}<0$ e $\beta_{2}>0$.

For the period over 1970 to 1999 several versions of equation (18) were estimated, for the 15 UE countries. It was possible to use 450 annual observations in the estimation of a panel data version of the previous equation,

$c_{i t}=a_{0}+a_{1} y_{i t}+\left(\alpha_{1} \Delta g_{i t}+\beta_{1} \Delta \tau_{i t}\right)+d_{t i}\left(\alpha_{2} \Delta g_{i t}+\beta_{2} \Delta \tau_{i t}\right)$

where the index $i$ denotes the country and the index $t$ stands for the period.

The values assumed by $d$, in order to signal the existence of a fiscal adjustment in a given year and country, result from the determination of the periods when there is a very expansionist or a very contracionist fiscal episode, as identified in Table 5 above.

Table 6 presents the results of the estimation of equation (19), and compares the fixed effects model with the pooled regression and the random effects model. 
Table 6 - Effects on private consumption of fiscal episodes

\begin{tabular}{|l|c|c|c|}
\hline $\begin{array}{l}\text { Variable } \\
\text { (coefficient) }\end{array}$ & $\begin{array}{c}\text { OLS, pooled } \\
\text { regression model }\end{array}$ & Fixed effects model & $\begin{array}{c}\text { Random effects } \\
\text { model }\end{array}$ \\
\hline Constant $\left(\mathrm{a}_{0}\right)$ & 0.6175 & - & 0.5927 \\
& $(3.878)$ & $(3.770)$ \\
\hline $\mathrm{y}\left(\mathrm{a}_{1}\right)$ & 0.7713 & 0.7963 & 0.7806 \\
& $(17.228)$ & $(17.015)$ & $(17.265)$ \\
\hline$\Delta \mathrm{g}\left(\alpha_{1}\right)$ & 0.1470 & 0.1739 & 0.1576 \\
& $(1.534)$ & $(1.807)$ & $(1.653)$ \\
\hline$\Delta \tau\left(\beta_{1}\right)$ & -0.1193 & -0.1453 & -0.1291 \\
& $(-1.076)$ & $(-1.313)$ & $(-1.173)$ \\
\hline $\mathrm{d} \Delta \mathrm{g}\left(\alpha_{2}\right)$ & -0.0773 & -0.1043 & -0.088 \\
& $(-0.679)$ & $(-0.913)$ & $(-0.781)$ \\
\hline $\mathrm{d} \Delta \tau\left(\beta_{2}\right)$ & 0.1194 & 0.1696 & 0.1385 \\
& $(0.831)$ & $(1.179)$ & $(0.969)$ \\
\hline$\overline{R^{2}}$ & & & 0.4560 \\
\hline F test $^{\text {a }}$ & 0.4560 & 0.4674 & \\
\hline Hausman test & & $1.6484^{*}$ & \\
& & $(14,410)$ & \\
\hline
\end{tabular}

The $\mathrm{t}$ statistics are in parentheses.

$\mathrm{a}$ - The degrees of freedman for the F statistic are in parentheses; the statistic tests the fixed effects model against the pooled regression model, where the autonomous term is the same for all countries, which is the null hypotheses.

b - The statistic has a Chi-square distribution (the degrees of freedom are in parentheses); the Hausman (1978) statistic tests the fixed effects model against the random effects, which is here the null hypotheses.

* - Statistically significant at the 10 percent level, the null hypotheses, of the pooled regression model, is rejected (this is a borderline call for the 10 percent level).

** - Not statistically significant, the null hypothesis is not rejected (random effects model), that is, one does not reject the hypotheses that the autonomous terms in each country are not correlated with the independent explanatory variables (in this case the random effects model produces unbiased and consistent estimators).

According to the results, in the absence of fiscal adjustments, $d=0$, the increase of public expenditures has a positive effect on the private consumption real growth rate, contributing therefore to an aggregate demand increase, as postulated by Keynesian theory. Also a contractionary fiscal policy exemplified by an increase of public taxes, results in private consumption reduction, when there are no fiscal adjustments. Notice that $\alpha_{1}$ is indeed positive and that $\beta_{1}$ is negative, in other words, we get the usual Keynesian effects. 
However, in the presence of fiscal episodes, identified by the rules described above, the effect on private consumption of an increase in public spending, is mitigated by the fact that the $\alpha_{2}$ coefficient is negative, as we previously hypothesised. That is, and according to the estimation results the fixed effects model, an expansionary fiscal policy, carried out by the increase in public spending, of one percentage point of GDP, has a less direct and significant (Keynesian) impact on private consumption. ${ }^{16}$ In fact, the original resulting change of 0,1739 percent of private consumption, is now reduced to 0,0696 percent $(0,0696=0,1793-0,1043)$, even if it still means a positive effect of public spending on private consumption.

A similar situation occurs with the change in public revenues, as can be seen for instance with the fixed effects model. An increase in public revenues, of one percentage point of GDP, in the absence of a fiscal episode would have a negative effect in private consumption of $-0,1453$ percentage points. However, in the presence of a fiscal episode, the effect on private consumption becomes even marginally expansionist in 0,0243 percentage points $(0,0243=-0,1453+0,1696)$, since we have now $\beta_{2}>0$ and the condition $\left|\beta_{2}\right|>\left|\beta_{1}\right|$ is also true in this example. ${ }^{17}$ Figure 3 illustrates the aforementioned examples of fiscal effects on private consumption.

\footnotetext{
${ }^{16}$ The results of the fixed effects model and of the random effects model are quite similar. Nevertheless, since we have a small cross-section number of observations, 15 countries that coincide with the relevant universe, and a much large number of time-series observations, the fixed effects model seems to be the appropriate choice.

${ }^{17}$ Notice that this condition is also verified, with the current data set, also for the pooled regression model and for the random effects model.
} 
Figure 3 - Effects of fiscal episodes, UE-15 (1970-1999)

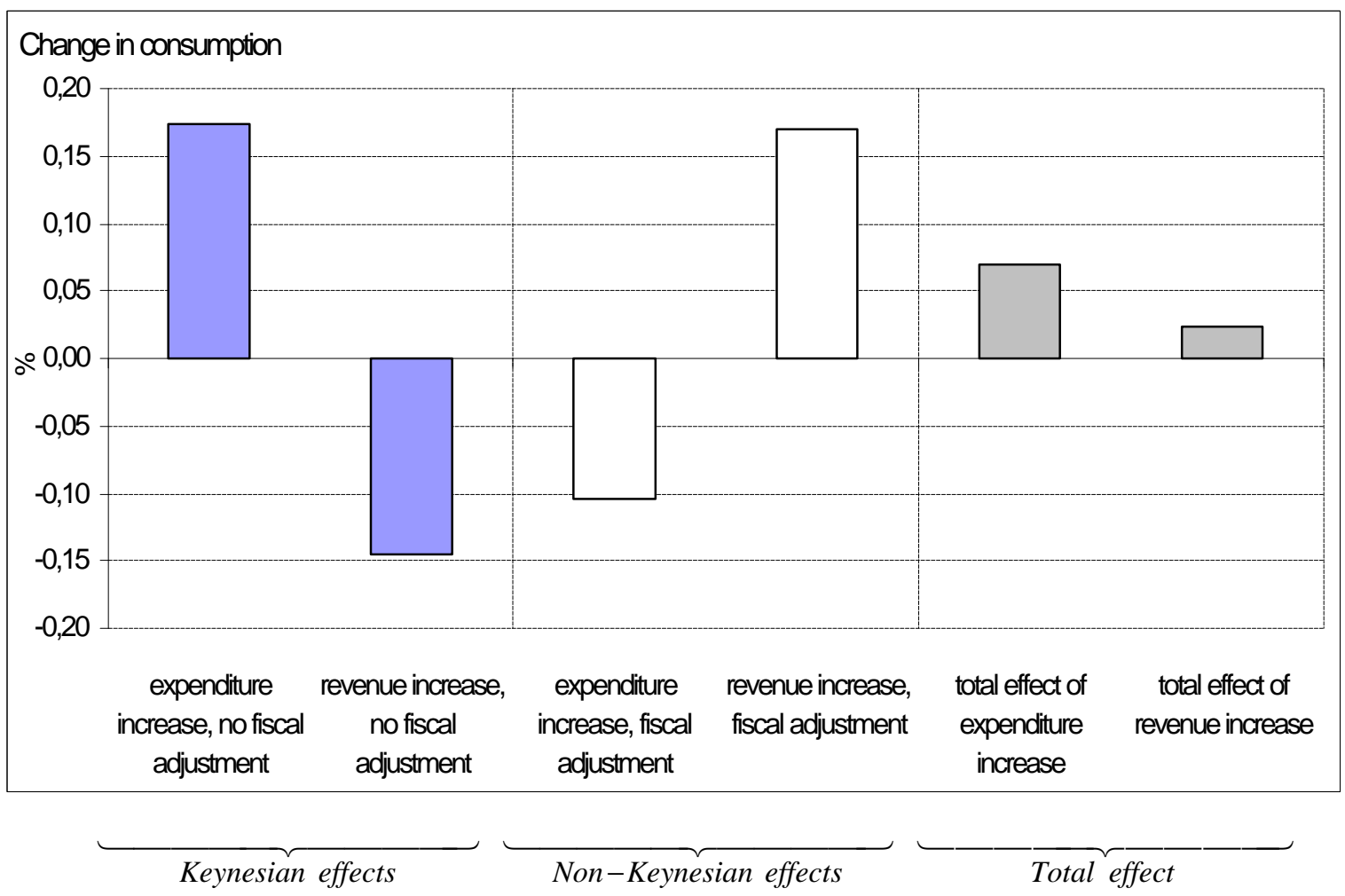

In order to investigate the possibility of non-Keynesian effects being more likely to occur when a fiscal episode is characterised by a fiscal contraction, rather than by a fiscal expansion, two artificial variables were constructed: $d^{C}$ to denote fiscal contraction episodes and $d^{E}$ to denote expansionist fiscal episodes. The two dummy variables assume the following values:

$d^{C}=\left\{\begin{array}{l}1, \text { when there is a contractionist fiscal episode } \\ 0, \text { when there is no contractionist fiscal episode; }\end{array}\right.$

$d^{E}=\left\{\begin{array}{l}1, \text { when there is an } \exp \text { ansionist fiscal episode } \\ 0, \text { when there is no } \exp \text { ansionist fiscal episode }\end{array}\right.$

The new model to test empirically is now 


$$
\begin{aligned}
c_{i t}=a_{0} & +a_{1} y_{i t}+\left(\alpha_{1} \Delta g_{i t}+\beta_{1} \Delta \tau_{i t}\right) \\
& +d_{i t}^{C}\left(\alpha_{2} \Delta g_{i t}+\beta_{2} \Delta \tau_{i t}\right)+d_{i t}^{E}\left(\alpha_{3} \Delta g_{i t}+\beta_{3} \Delta \tau_{i t}\right),
\end{aligned}
$$

and the results from the estimation are presented in Table 7.

Table 7 - Effects on private consumption of fiscal episodes, different dummy variables for contractionist and expansionist fiscal episodes

\begin{tabular}{|l|c|c|c|}
\hline $\begin{array}{l}\text { Variable } \\
\text { (coefficient) }\end{array}$ & $\begin{array}{c}\text { OLS, pooled } \\
\text { regression model }\end{array}$ & $\begin{array}{c}\text { Fixed effects } \\
\text { model }\end{array}$ & $\begin{array}{c}\text { Random effects } \\
\text { model }\end{array}$ \\
\hline Constant $\left(\mathrm{a}_{0}\right)$ & 0.5825 & - & 0.5484 \\
& $(3.429)$ & & $(2.943)$ \\
\hline $\mathrm{y}\left(\mathrm{a}_{1}\right)$ & 0.7719 & 0.8003 & 0.7818 \\
& $(17.126)$ & $(16.844)$ & $(17.135)$ \\
\hline$\Delta \mathrm{g}\left(\alpha_{1}\right)$ & 0.1472 & 0.1773 & 0.1583 \\
& $(1.534)$ & $(1.836)$ & $(1.657)$ \\
\hline$\Delta \tau\left(\beta_{1}\right)$ & -0.1187 & -0.1480 & -0.1292 \\
& $(-1.069)$ & $(-1.335)$ & $(-1.172)$ \\
\hline $\mathrm{d}^{\mathrm{C}} \Delta \mathrm{g}\left(\alpha_{2}\right)$ & -0.1088 & -0.1785 & -0.1343 \\
& $(-0.782)$ & $(-1.240)$ & $(-0.961)$ \\
\hline $\mathrm{d}^{\mathrm{C}} \Delta \tau\left(\beta_{2}\right)$ & 0.1930 & 0.2752 & 0.2228 \\
& $(1.162)$ & $(1.608)$ & $(1.336)$ \\
\hline $\mathrm{d}^{\mathrm{E}} \Delta \mathrm{g}\left(\alpha_{3}\right)$ & -0.0513 & -0.0433 & -0.0494 \\
& $(-0.386)$ & $(-0.323)$ & $(-0.374)$ \\
\hline $\mathrm{d}^{\mathrm{E}} \Delta \tau\left(\beta_{3}\right)$ & -0.0623 & -0.0020 & -0.0414 \\
& $(-0.310)$ & $(-0.011)$ & $(-0.206)$ \\
\hline$-R^{2}$ & & & \\
\hline F test ${ }^{\mathrm{a}}$ & 0.4557 & 0.4668 & 0.4556 \\
\hline Hausman test ${ }^{\mathrm{b}}$ & & $1.6324 *$ & \\
\hline
\end{tabular}

The t statistics are in parentheses.

a - The degrees of freedman for the F statistic are in parentheses; the statistic tests the fixed effects model against the pooled regression model, where the autonomous term is the same for all countries, which is the null hypotheses.

b - The statistic has a Chi-square distribution (the degrees of freedom are in parentheses); the Hausman (1978) statistic tests the fixed effects model against the random effects, which is here the null hypotheses.

* - Statistically significant at the 10 percent level, the null hypotheses, of the pooled regression model, is rejected (this is again a close call for this significance level).

** - Not statistically significant, the null hypothesis is not rejected (random effects model), that is, one does not reject the hypotheses that the autonomous terms in each country are not correlated with the independent explanatory variables (in this case the random effects model produces unbiased and consistent estimators). 
The results from the previous table allow us to conclude that fiscal episodes characterised by fiscal contractions seem to be more favourable to the emergence of fiscal policy non-Keynesian effects. ${ }^{18}$ In fact, and using the estimated coefficients from the fixed effects model, the rise of public expenditures has the usual positive effect on private consumption, in the absence of a fiscal episode: 0,1773 percentage points. However, this positive effect is completely reversed when there is a contractionist fiscal episode, the effect on private consumption becoming even slightly negative: $-0,0012$ percent $(-0,0012=0,1773-0,1785)$.

An identical result is detected in the case of an increase of public revenues, when the Keynesian effect on private consumption, of $-0,1489$ percent, valid in the absence of fiscal episodes, is totally reversed when there is a contractionist fiscal episode. In this case, the effect on private consumption of an increase in public revenues, changes to 0,1271 percent $(0,1271=-0,1480+0,2752)$.

In the situations where there are expansionist fiscal episodes, the total effect on private consumption remains nevertheless quite Keynesian. Figure 4 represents the main conclusions for the case where fiscal contractions occur.

\footnotetext{
${ }^{18}$ Even if in a moderate way, due to the values of the $t$ statistics.
} 
Figure 4 - Effects of contractionist fiscal episodes, EU-15 (1970-1999), specific dummy variables for expansions and contractions

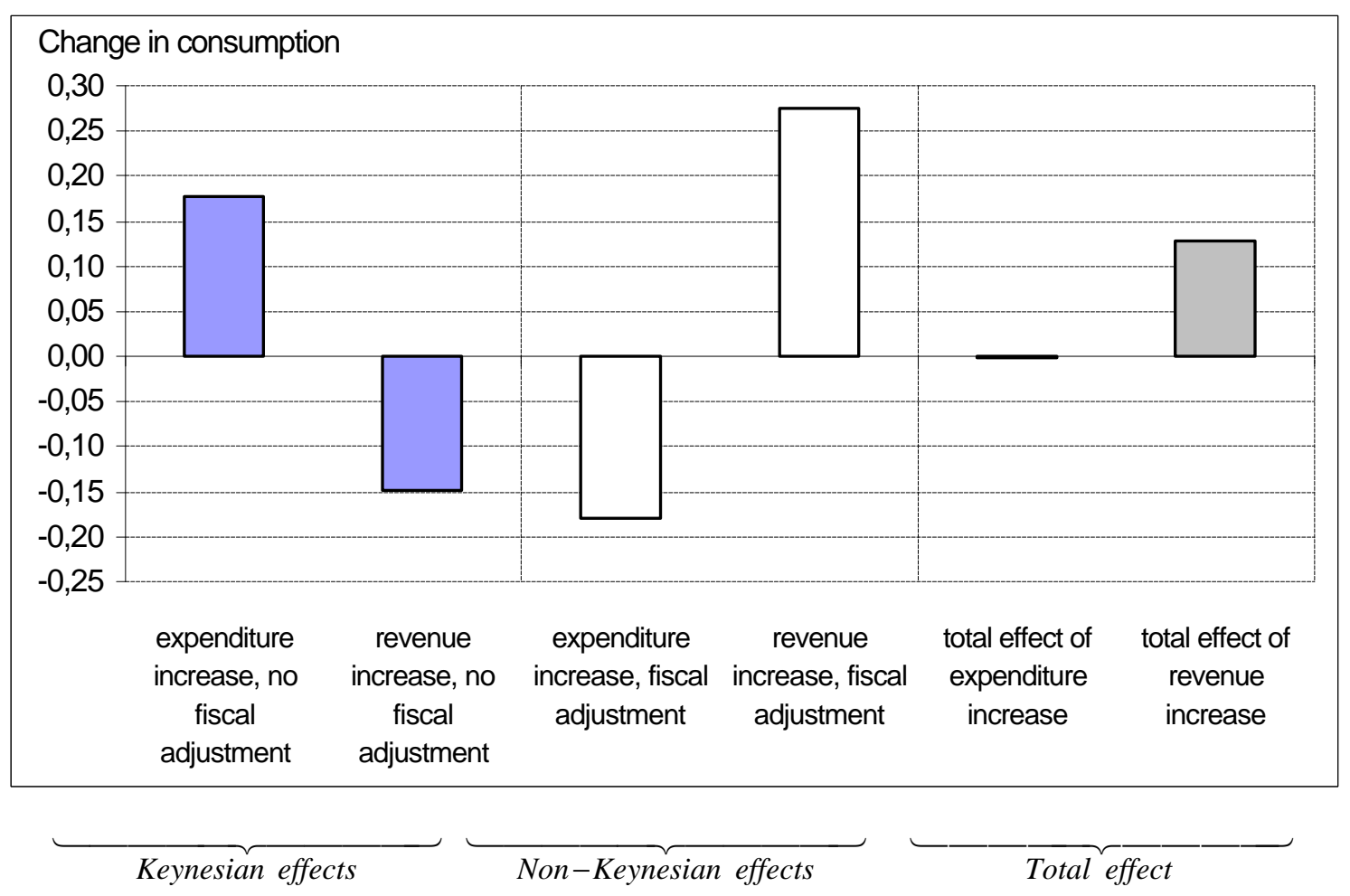

An additional conclusion seems therefore to be the fact that there are asymmetric (or non-linear) effects of fiscal policy, particularly in the way the non-Keynesian effects take place. Similar conclusion concerning the non-linear effects of fiscal policy is presented by Giavazzi et al. (2000).

One may recall that through the multiplier mechanism, the reduction of public expenditures will produce a private consumption contraction bigger than the contraction brought about by a tax increase (since the marginal propensity to consume is bellow unity). This may indeed be relevant to understand the magnitude of non-Keynesian effects considering different fiscal consolidation compositions, namely the possibility of non-Keynesian fiscal policy asymmetrical effects. The empirical evidence presented above seems to corroborate this point for the EU-15. 


\section{3 - The success of fiscal consolidations}

In the previous section several fiscal contractions were identified, and Table 5 reported the periods of very important fiscal contractions. It seems therefore relevant to investigate which were the fiscal contractions that can be labelled as successful, meaning that they contributed to a sustained decrease of the government responsibilities.

A successful fiscal contraction is then defined as a fiscal contraction that results in the decrease of the debt-to-GDP ratio in the years following the fiscal adjustment. More exactly, in order to consider a fiscal contraction as successful, three years after the fiscal adjustment the debt-to-GDP ratio must be five-percentage points bellow the value observed in the last year of the adjustment (Criterion 1). ${ }^{19}$ Alternatively to this first definition, one may use a more strict criterion, where a fiscal consolidation is labelled as successful, when two years after the fiscal adjustment the debt-to-GDP ratio is three percentage points bellow the value of the last year of the adjustment (Criterion 2).

Using the two previous definitions of successful fiscal contraction, it was possible to identify, with first criterion, 16 periods for the EU-15 countries, between 1970 and 1999, which share such a debt-to-GDP decrease. With the second criterion, the number of successful fiscal adjustments is basically the same, 17, the main difference being that the fiscal contractions in Spain, in 1986 and in 1996, are only considered as a success with the less demanding criterion. All cases of successful fiscal contractions, identified by both criteria, are reported in Table 8 .

\footnotetext{
${ }^{19}$ McDermott and Westcott (1996), Alesina, Perotti and Tavares (1998) and Zaghini (1999) adopt similar definitions.
} 
Table 8 - Successful fiscal contractions in the EU-15 (1970-1999)

\begin{tabular}{|l|l|c|c|c|}
\hline \multirow{2}{*}{ Country } & \multicolumn{1}{c|}{$\begin{array}{c}\text { Fiscal } \\
\text { contraction } \\
\text { period }\end{array}$} & $\begin{array}{c}\text { Last year of } \\
\text { the period }\end{array}$ & Criterion 1 & Criterion 2 \\
\hline Belgium & 1993 & 137,3 & 9,3 & 5,1 \\
\hline Denmark & $1983-84$ & 75,1 & 15,5 & 11,4 \\
\hline Finland & 1971 & 14,1 & 5,8 & 3,6 \\
& 1996 & 57,8 & 11,6 & 8,2 \\
& 1998 (a) & 49,6 & 7,0 & 7,0 \\
\hline Greece & 1996 & 112,2 & 6,8 & 5,7 \\
\hline Ireland & $1987-1988$ & 112,4 & 19,8 & 19,1 \\
& $1993-94$ & 86,5 & 25,2 & 17,1 \\
\hline Italy & $1996-1997$ & 122,4 & 11,6 & 6,4 \\
\hline Netherlands & 1996 & 77,0 & 10,0 & 9,3 \\
\hline Portugal & 1986 & 66,8 & 5,0 & 3,0 \\
& 1995 & 64,7 & 8,2 & 4,4 \\
\hline Spain & 1986 & 45,1 & $(b)$ & 3,7 \\
& 1996 & 68,6 & (b) & 3,0 \\
\hline Sweden & 1987 & 76,2 & 12,9 & 10,9 \\
& 1996 & 45,1 & 6,6 & $(\mathrm{c})$ \\
\hline United Kingdom & $1996-1998$ (a) & & 13,8 & 13,8 \\
\hline & 1998 (a) & & 7,0 & 7,0 \\
\hline
\end{tabular}

Criterion 1 - Reduction of 5 percentage points after 3 years;

Criterion 2 - Reduction of 3 percentage points after 2 years.

(a) For Finland, United Kingdom and Sweden, for the 1998 adjustments, the forecasted value for the debt-to-GDP ratio for 2000 was used. This means that for the first criterion, it was only possible to use data for two years after the adjustment.

(b) Change in debt-to-GDP ratio bellow 5 percentage points.

(c) Change in debt-to-GDP ratio bellow 3 percentage points.

It is also possible to conclude, from the previous table, that among the successful fiscal consolidations, ten occurred in the $90 \mathrm{~s}$, five in the $80 \mathrm{~s}$ and one in the $70 \mathrm{~s}$, in Finland (even if the small debt-to-GDP ratio at the time, 14,1 percent, reduces the 
importance of the adjustment). The fact that most of the fiscal contractions took place in the 90s, is no doubt a consequence of the efforts made by the European countries to fulfil the budgetary criteria, imposed on them after the signing of the Maastricht Treaty in 1992. Notice once more that the criteria used in this paper, to determine the successful fiscal consolidations, correctly identifies the aforementioned episodes of Denmark (198384), Ireland (1987-88) and Portugal (1986).

With the successful fiscal consolidations identified above, using the first criterion, (reduction of the debt-to-GDP ratio in 5 percentage points), an attempt was made to assess the importance of the size and of the composition of the fiscal adjustment, in generating a successful consolidation.

One of the purposes is then to investigate whether a successful fiscal adjustment is more likely to occur when there are bigger increases of the primary structural budget balance. It is also interesting to evaluate if a fiscal consolidation based on spending cuts rather than on tax increases, has a better probability of being successful.

To answer those questions a Logit model was estimated, defining

$$
P_{i}=E\left[S=1 \mid Z_{i}\right]=\frac{e^{Z_{i}}}{1+e^{Z_{i}}}
$$

where $E\left[S=1 \mid Z_{i}\right]$, the conditional expectation of the success of a fiscal consolidation, given $Z_{i}$, with $S=\left\{\begin{array}{l}1, \text { if the consolidation is successful, } \\ 0, \text { if the consolidation is not successful; }\end{array}\right.$

can be interpreted as the conditional probability that a successful consolidation occurs given $Z_{i}$, with 
$Z_{i}=\alpha+\beta B_{i}+\gamma D_{i}+\delta \bar{y}_{i}$,

and where $B$ is the change in the primary structural budget balance; $D$ is a dummy variable that assumes the value 1 when the reduction of the primary structural public spending is at least $2 / 3$ of the increase in the primary structural budget balance, and 0 otherwise.

Finally, and to control the effects of real economic growth, in the national economies and in the EU-15, $\bar{y}$ is the difference between the average three years real growth rate in each country after the fiscal consolidation (including the last consolidation year) and the same average real growth rate for the EU-15, that is,

$\bar{y}_{i}=\sum_{j=0}^{2}\left(y_{i+j}^{X}-y_{i+j}^{E U 15}\right) / 3$

and $y^{X}$ and $y^{E U 15}$ are respectively the real GDP growth rate in country $X$ and in the EU15. The three years real growth rate average is selected because one decides on the success of a fiscal consolidation, by screening the debt-to-GDP ratio also three years after the fiscal consolidation. ${ }^{20}$

The results of the estimations, using criterion 1, are presented in Table 9.

\footnotetext{
${ }^{20}$ For instance McDermott and Westcott (1996) use only the GDP growth rate in the year of the consolidation even if they analyse the debt-to-GDP ratio 3 years after the consolidation.
} 
Table 9 - Logit model for successful fiscal consolidations in the EU-15 (1970-1999)

\begin{tabular}{|c|c|c|}
\hline Coefficient & Model 1 & Model 2 \\
\hline$\alpha$ & -0.8502 & \\
& $(-1.26)$ & \\
\hline$\beta$ & 0.2096 & 0.4888 \\
$(0.85)$ & $(3.59)$ \\
\hline$\gamma$ & 0.7529 & 0.6707 \\
& $(1.28)$ & $(1.13)$ \\
\hline$\delta$ & 0.3368 & 0.3155 \\
& $(2.34)$ & $(2.18)$ \\
\hline Log likelihood & -39.893 & -40.679 \\
\hline Pseudo- $R^{2}$ & 0.137 & 0.116 \\
\hline
\end{tabular}

The $\mathrm{t}$ statistics are in parentheses. The pseudo- $\mathrm{R}^{2}$ statistic is the alternative measure of goodness of fit proposed by Estrella (1998), and is given by $1-\left(\log L_{u} / \log L_{c}\right)^{-\frac{2}{n} \log L_{c}}$, where $L_{u}$ denotes the likelihood of the estimated model, $L_{c}$ the likelihood of a model incorporating solely a constant as regressor, and the $n$ the number of observations.

Even if the results are not completely satisfactory, statistically speaking, it is nevertheless possible to tentatively advance some conclusions. For instance, the bigger the dimension of the increase in the primary structural budget balances the bigger the probability of a fiscal consolidation being successful. Also, the probability of success is higher when the reduction in primary public spending is more significant (at least $2 / 3$ of the increase in the primary structural budget balance).

Figure 5 illustrates the estimation results for the second model in Table 9, through a simple simulation exercise. ${ }^{21}$ For instance, an increase of 2 percentage points of GDP in the primary structural budget balance increases the probability of getting a successful fiscal consolidation by 10 per cent. ${ }^{22}$

\footnotetext{
${ }^{21}$ In model 2, $y$ is fixed, for the graphical simulation, at the average value of the sample, 0,61 percent.

${ }^{22}$ Additional models without the real GDP growth rate as an explanatory variable were also estimated (results available from the author upon request) but there were no statistical improvements.
} 
Figure 5 - Probability of success of a fiscal consolidation

(with model 2 of Table 9)

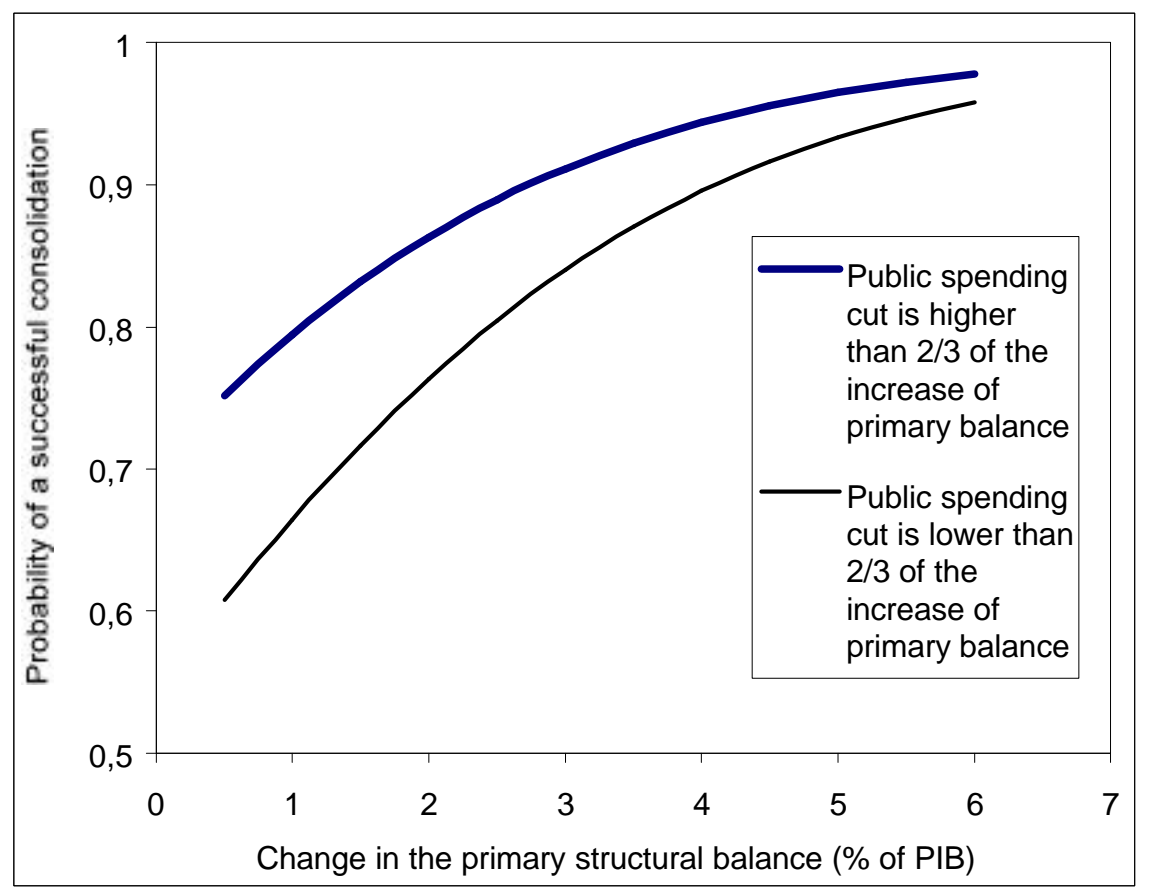

Further estimations were made using criterion 2, also an alternative threshold 3/4 was used, instead of the initial limit of $2 / 3$ for public spending contribution in reducing the primary deficit. Luxembourg was also excluded from the data set, since the budgetary variables have some missing values for this country. However, and since the quality of the estimations did not improve, those results are not presented due to space restrictions.

\section{6 - Conclusion}

This paper presented a model with two periods for private consumption in order to explain the possibility of both Keynesian and non-Keynesian effects of fiscal policy, the main feature being the relation between interest rate and taxes and the existence of rationed consumers. One of the conclusions is that the bigger the proportion of nonrationed consumers the bigger the probability for the occurrence of non-Keynesian effects. Also, when the interest rate is more responsive to changes in public revenues, the existence of non-Keynesian effects is more likely. 
In the empirical part of the paper, fiscal episodes are determined according to a simple statistical approach, using the first difference of the primary structural budget balance, in order to classify fiscal policy as very expansionist, expansionist, neutral, contractionist or very contractionist. The resulting fiscal episodes for the EU-15 countries between over the period 1961 to 1999 , allow to us correctly identify the well-known fiscal contractions of Denmark in 1983-84 and Ireland in 1987-88.

The estimation results, with fixed effects and random effects panel data models, show that the usual positive effect on consumption of an increase in public expenditures is somehow mitigated when a fiscal episode occurs. In the case of an increase of public revenues, the expected negative effect on private consumption may even be reversed. In addition, the estimated non-Keynesian effects are asymmetric, with the change in public spending being more likely to produce such effects. The findings of this paper are therefore in line with some of the previous empirical literature, namely Alesina and Ardagna (1998), Zaghini (1999) and Miller and Russek (1999).

Concerning the labelling of successful fiscal consolidations, two success criteria are defined, according to the evolution of the debt-to-GDP ratio after the fiscal adjustment. Once again, both criteria are able to correctly classify the aforementioned fiscal consolidations of Ireland and Denmark as successful. An attempt is made to evaluate if the probability of success of a fiscal consolidation is higher when there is a more significant reduction in public spending. Even if the results are not completely satisfactory in statistical terms, the answer seems to be tentatively affirmative. 


\section{Appendix A - Derivation of non-Keynesian effects of fiscal policy on private consumption}

Starting from equation (9) in the text, repeated bellow,

$$
\frac{\partial C_{1}}{\partial T_{1}}=-\lambda+\left(\frac{1-\lambda}{1+\rho}\right)\left\{-1+\frac{\left[\frac{\partial Y_{2}}{\partial T_{1}}-\frac{\partial T_{2}}{\partial T_{1}}\right](1+r)-\left(Y_{2}-T_{2}\right) \frac{\partial r}{\partial T 1}}{(1+r)^{2}}\right\}
$$

it is possible to write

$$
\begin{aligned}
& \frac{\partial C_{1}}{\partial T_{1}}=-\lambda+\left(\frac{1-\lambda}{1+\rho}\right)\left\{-1+\frac{\left[\frac{\partial Y_{2}}{\partial T_{1}}-\frac{\partial T_{2}}{\partial T_{1}}\right]}{(1+r)}-\frac{Y_{2}-T_{2}}{(1+r)^{2}} \frac{\partial r}{\partial T_{1}}\right\} \\
& \frac{\partial C_{1}}{\partial T_{1}}=-\lambda+\left(\frac{1-\lambda}{1+\rho}\right)\left\{-1+\frac{1}{1+r}\left[\frac{\partial Y_{2}}{\partial I_{2}} \frac{\partial I_{2}}{\partial r} \frac{\partial r}{\partial T_{1}}-\frac{\partial T_{2}}{\partial T_{1}}\right]-\frac{Y_{2}-T_{2}}{(1+r)^{2}} \frac{\partial r}{\partial T_{1}}\right\} .
\end{aligned}
$$

Using the inter-temporal government budget constraint

$$
T_{1}+\frac{T_{2}}{1+r}+\frac{B_{2}}{1+r}=\bar{G}_{1}+\frac{\bar{G}_{2}}{1+r}
$$

it is obvious that

$\frac{\partial T_{2}}{\partial T_{1}}=-(1+r)$

a result that can be substituted into (A3)

$$
\begin{aligned}
& \frac{\partial C_{1}}{\partial T_{1}}=-\lambda+\left(\frac{1-\lambda}{1+\rho}\right)\left\{-1+\frac{1}{1+r}\left[\frac{\partial Y_{2}}{\partial I_{2}} \frac{\partial I_{2}}{\partial r} \frac{\partial r}{\partial T_{1}}+(1+r)\right]-\frac{Y_{2}-T_{2}}{(1+r)^{2}} \frac{\partial r}{\partial T_{1}}\right\} \\
& \frac{\partial C_{1}}{\partial T_{1}}=-\lambda+\left(\frac{1-\lambda}{1+\rho}\right)\left\{-1+\frac{1+r}{1+r}+\frac{1}{1+r}\left[\frac{\partial Y_{2}}{\partial I_{2}} \frac{\partial I_{2}}{\partial r} \frac{\partial r}{\partial T_{1}}\right]-\frac{Y_{2}-T_{2}}{(1+r)^{2}} \frac{\partial r}{\partial T_{1}}\right\}
\end{aligned}
$$


in order to get the result presented in the text

$$
\frac{\partial C_{1}}{\partial T_{1}}=-\lambda+\left(\frac{1-\lambda}{1+\rho}\right)\left(\frac{\partial r}{\partial T_{1}}\right)\left[\frac{1}{1+r} \frac{\partial Y_{2}}{\partial I_{2}} \frac{\partial I_{2}}{\partial r}-\frac{Y_{2}-T_{2}}{(1+r)^{2}}\right]
$$

\section{Appendix B - Statistical sources}

Series from $\mathrm{AMECO}^{23}$ according to the ESA95 methodology:

- Cyclically adjusted net lending (+) or net borrowing (-) of general government (Percentage of gross domestic product at market prices). AMECO Code: TI0000000ABLGA.

- Net lending (+) or net borrowing (-) excluding interest payments of general government adjusted for the cyclical component (Percentage of gross domestic product at market prices). AMECO Code: TI0000000ABLGB.

- Total public expenditure adjusted for the cyclical component, excluding interest payments (Percentage of gross domestic product at market prices). AMECO Code: TI0000000AUTGB.

- Total public receipts adjusted for the cyclical component (Percentage of gross domestic product at market prices). AMECO Code: TI0000000AUTGA.

- Private final consumption expenditure at constant prices (1990 prices), national currency. Aggregates: chain weighted, Mrd ECU or Euro base year. AMECO Code: $1100 \mathrm{OCPH}$.

- Gross Domestic Product at constant market prices, total economy (1990 prices), national currency. Aggregates: chain weighted, Mrd ECU or Euro base year. AMECO Code: 11000 VGD.

- Debt-to-GDP ratio: European Economy, 69, 1999; European Economy, Supplement A, no 1/2, April 2000.

23 AMECO (ANNUAL MACRO ECONOMIC DATABASE): European Commission, Directorate General, Economic and Financial Affairs, Directorate A: Economic studies and research; Unit 2: Economic databases and statistical co-ordination; Sector: Macro-economic database. 


\section{References}

Afonso, A. (1999). "Public Debt Neutrality and Private Consumption: some Evidence from the Euro Area," Research and Forecasting Department, Ministry of Finance, Working Paper 11, June.

Afonso, A. (2000). "Fiscal Policy Sustainability: Some Unpleasant European Evidence," Department of Economics, ISEG-UTL, Working Paper 12/2000/DE.

Alesina, A. and Ardagna, S. (1998). "Tales of Fiscal Contractions," Economic Policy, 27, 487-545.

Alesina, A. and Perotti, R. (1995). "Fiscal Expansions and Adjustments in OECD countries," Economic Policy, 21, 205-248.

Alesina, A. and Perotti, R. (1997). "Fiscal Adjustments in OECD countries: Composition and Macroeconomic Effects," International Monetary Fund Staff Papers, 44 (2), 210-248.

Alesina, A.; Perotti, R. and Tavares, J. (1998). "The Political Economy of Fiscal Adjustments," Brookings Papers on Economic Activity, 1, 197-266.

Artus, P. (1996). "Austérité Budgétaire, Crédibilité et Comportment de Consommation," Économie Internationale, 68, 4th trimester, 59-82.

Artus, P. (1997). "Vitesse de réduction des déficits publics et incertitude sur les objectifs des autorités," Révue d'Économie Politique, 107 (6), 809-830.

Athanasios, P., Sidiropoulos, M. (1999). "The Sustainability of Fiscal Policies in the European Union," International Advances in Economic Research, 5 (3), 289-307.

Barrel, R.; Morgan, J.; Sefton, J. and int' t Veld, . (1994). "The cyclical adjustment of budget balances," NIESR Report Series $n^{\circ} 8$.

Barry, F. (1991). "The Irish Recovery 1987-90: An Economic Miracle?" The Irish Banking Review, Winter, 23-40.

Barry, F. and Devereux, M. (1995). "The 'Expansionary Fiscal Contraction' Hypothesis: A Neo-Keynesian Analysis," Oxford Economic Papers, 47, 249-264.

Bergman, U. and Hutchison, M. (1997). "Economic Expansions and Fiscal Contractions: International Evidence and the 1982 Danish Stabilization," University of California at Santa Cruz, Department of Economics, Working Paper 386. 
Bertola, G. and Drazen, A. (1993). "Trigger Points and Budget Cuts: Explaining the Effects of Fiscal Austerity," American Economic Review, 83 (1), 11-26.

Bhattacharya, R. (1999). "Private Sector Consumption Behavior and Non-Keynesian Effects of Fiscal Policy," IMF Working Paper 99/112. June.

Blanchard, O. (1990). "Comment, on Giavazzi and Pagano (1990)," in Blanchard, O. and Fischer, S. (eds.), NBER Macroeconomics Annual 1990, 111-116.

Blanchard, O. (1993). "Suggestions for a new set of fiscal indicators," in Verbon, A. and Winden, F. (eds.), The Political Economy of Government Debt, North-Holland.

Blanchard, O. (2000). Macroeconomics, 2nd ed., Prentice Hall.

Blejer, M. and Cheasty, A. (1991). "The Measurement of Fiscal Deficits: Analytical Methodological Issues," Journal of Economic Literature, 29 (4), 1644-1678.

Blinder, A. (1997). "Is There a Core of Practical Macroeconomics that We Should All Believe?" American Economic Review, Papers and Proceedings, 87 (2), 240-243.

Bradley, J. and Whelan, K. (1997). "The Irish expansionary fiscal contraction: A tale from one small European economy," Economic Modelling, 14 (2), 175-201.

Brandner, P.; Diebalek, L. and Schuberth, H. (1998). "Structural Budget Deficits and Sustainability of Fiscal Positions in the European Union," Working Paper $\mathrm{n}^{\circ}$ 26, Oesterreichische Nationalbank, February.

Cebula, R. (1997). "An Empirical Note on the Impact of the Federal Budget Deficit on Ex Ante Real Long-Term Interest Rates, 1975-1995," Southern Economic Journal, 63 (4), 1094-1099.

Cour, P.; Dubois, E.; Mahfouz, S. and Pisani-Ferry. J. (1996). "The Costs of Fiscal Adjustment Revisited: how Strong is the Evidence?" CEPII Working Paper 96-16.

Creel, J. (1998). "Contractions Budgétaires et Contraintes de Liquidité: les Cas Danois et Irlandais," Économie Internationale, 75, 3rd trimester, 33-54.

De Ménil, G. (1996). "Les politiques budgétaires en Europe à la veille de l' Union Monétaire," Économie Internationale, 68, 4th trimester, 31-55.

Dornbusch, R. (1989). "Credibility, debt and unemployment: Irelands' $\mathrm{s}$ failed stabilization," Economic Policy, 8, 174-210.

EC (1995). "Technical Note: The Commissions Services' Method for the Cyclical Adjustment of Government Budget Balances," European Economy, 60. 
Estrella, A. (1998). "A New Measure of Fit for Equations With Dichotomous Dependent Variables," Journal of Business \& Economic Statistics, 16 (2), 198-205.

Feldstein, M. (1982). "Government Deficits and Aggregate Demand," Journal of Monetary Economics, 9 (1), 1-20.

Giavazzi, F. and Pagano, M. (1990). "Can Severe Fiscal Contractions be Expansionary? Tales of Two Small European Countries," in Blanchard, O. and Fischer, S. (eds.), NBER Macroeconomics Annual 1990, MIT Press.

Giavazzi, F. and Pagano, M. (1996). "Non-keynesian Effects of Fiscal Policy Changes: International Evidence and the Swedish Experience," Swedish Economic Policy Review, 3 (1), 67-103.

Giavazzi, F.; Jappelli, T. and Pagano, M. (2000). "Searching for non-linear effects of fiscal policy: evidence from industrial and developing countries," European Economic Review, 44 (7), 1259-1289.

Giorno, C.; Richardson, P.; Roseveare, D. and van den Noord, P. (1995). "Potencial Output, Output Gaps and Structural Budget Balances," OECD Economic Studies, 24, 167-208.

Giorno, C and Suyker, W. (1997). "Les estimations de 1' écart de production de l'OCDE," Économie Internationale, 69, 1st trimester, 109-134.

Hausman, J. (1978). "Specification Tests in Econometrics," Econometrica, 46 (6), 12511271.

Heller, P.; Haas, R. and Mansur, A. (1986). "A Review of the Fiscal Impulse Measure," FMI Occasional Paper no 44, May.

Heylen, F. and Everaert, G. (2000). "Success and Failure of Fiscal Consolidation in the OECD: A Multivariate Analysis," Public Choice, 105 (1/2), 103-124.

Ibrahim, S. and Kumah, F. (1997). "Comovements in budget deficits, money, interest rates, exchange rates and the current account balance: some empirical evidence," Applied Economics, 28 (1), 117-130.

IMF (1993). "Structural Budget Indicators for the Major Industrial Countries," World Economic Outlook, 99-103, October.

IMF (1995). "Structural Fiscal Balances in Smaller Industrial Countries," World Economic Outlook, May. 
Kormendi, R. and Meguire, P. (1990). "Government Debt, Government Spending, and Private Sector Behavior: Reply and Update," American Economic Review, 80 (3), 604617.

Leibfritz, W.; Roseveare, D. and van den Noord, P. (1994). "Fiscal Policy, Government Debt and Economic Performance," OCDE Working Paper n ${ }^{\circ} 144$.

McDermott, C. and Wescott, R. (1996). "An Empirical Analysis of Fiscal Adjustments," International Monetary Fund Staff Papers, 43 (4), 725-753.

Miller, S. and Russek, F. (1999). "The Relationship between large fiscal adjustments and short-term output growth under alternative fiscal policy regimes," University of Connecticut Working Paper.

Missale, A., Giavazzi, F., and Benigno, P. (1997). "Managing the public debt in fiscal stabilizations: the evidence," NBER Working Paper 6311, December.

Modigliani, F and Sterling, F. (1986). "Government Debt, Government Spending, and Private Sector Behavior: Comment," American Economic Review, LIX (5), 1168-1174.

Modigliani, F and Sterling, F. (1990). "Government Debt, Government Spending, and Private Sector Behavior: A Further Comment," American Economic Review, 80, 600-604.

OECD (1996). "The experience with fiscal consolidation in OECD countries," Economic Outlook, 59, June, 33-41.

OECD (1999). "The size and role of automatic fiscal stabilisers, " Economic Outlook, 68, December, 137-149.

Ongena, H. and Roger, W. (1997). "Les estimations de l'écart de production de la commission Européene," Économie Internationale, 69, 1st trimester, 77-95.

Perotti, R. (1996). "Fiscal Consolidation in Europe: Composition Matters," American Economic Review, Papers and Proceedings, 86 (2), 105-110.

Perotti, R. (1998). "The Political Economy of Fiscal Consolidations," Scandinavian Journal of Economics, 100 (1) 367-394.

Perotti, R. (1999). "Fiscal Policy in Good Times and Bad," Quarterly Journal of Economics, 114 (4) 1399-1436.

Rose, D. and Hakes, D. (1995). "Deficits and Interest Rates as Evidence of Ricardian Equivalence,” Eastern Economic Journal, 21 (1), 57-66.

Sutherland, A. (1997). "Fiscal Crises and Aggregate Demand: Can High Public Debt Reverse the Effects of Fiscal Policy?," Journal of Public Economics, 65 (2), 147-162. 
Uctum, M. and Wickens, M. (2000). "Debt and deficit ceilings, and sustainability of fiscal policies: an intertemporal analysis," Oxford Bulletin of Economic Research, 62 (2), 197-222.

Whelan, K. (1991). "Ricardian Equivalence and the Irish Consumption Function: The Evidence Re-examined," The Economic and Social Review, 22 (3), 229-238.

Zaghini, A. (1999). "The Economic Policy of Fiscal Conditions: The European Experience," Banca d' Italia, Temi di Discussione, nº 355, June. 